\title{
LEVEL II SCOUR ANALYSIS FOR BRIDGE 137 (FERRUS00070137) on U.S. ROUTE 7, crossing \\ LITTLE OTTER CREEK, FERRISBURG, VERMONT
}

U.S. Geological Survey Open-File Report 97-189

Prepared in cooperation with

VERMONT AGENCY OF TRANSPORTATION and

FEDERAL HIGHWAY ADMINISTRATION 


\section{LEVEL II SCOUR ANALYSIS FOR BRIDGE 137 (FERRUS00070137) on U.S. ROUTE 7, crossing \\ LITTLE OTTER CREEK, FERRISBURG, VERMONT}

By Erick M. Boehmler and Ronda L. Burns

U.S. Geological Survey Open-File Report 97-189

Prepared in cooperation with

VERMONT AGENCY OF TRANSPORTATION

and

FEDERAL HIGHWAY ADMINISTRATION

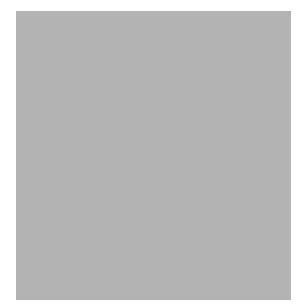




\title{
U.S. DEPARTMENT OF THE INTERIOR BRUCE BABBITT, Secretary
}

\author{
U.S. GEOLOGICAL SURVEY \\ Gordon P. Eaton, Director
}

For additional information write to:

District Chief

U.S. Geological Survey 361 Commerce Way

Pembroke, NH 03275-3718
Copies of this report may be purchased from:

U.S. Geological Survey

Branch of Information Services

Open-File Reports Unit

Box 25286

Denver, CO 80225-0286 


\section{CONTENTS}

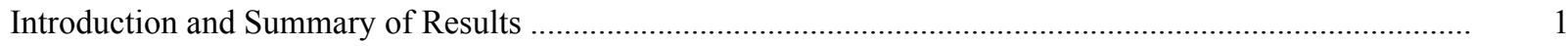

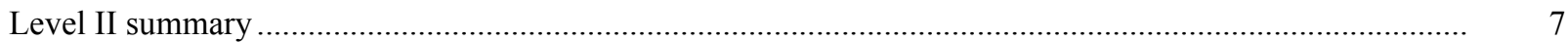

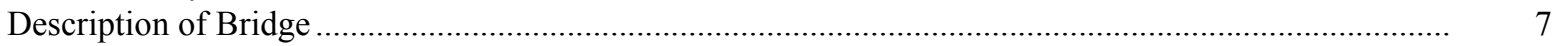

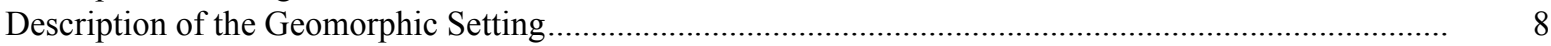

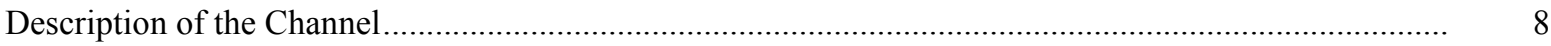

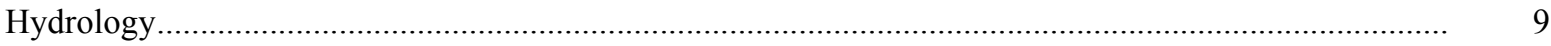

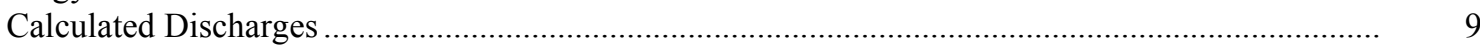

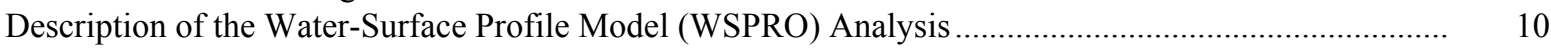

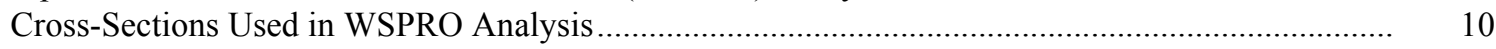

Data and Assumptions Used in WSPRO Model ..................................................................... 11

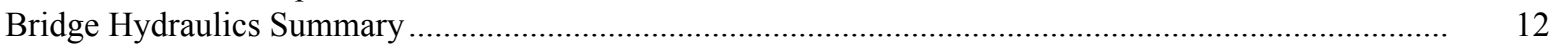

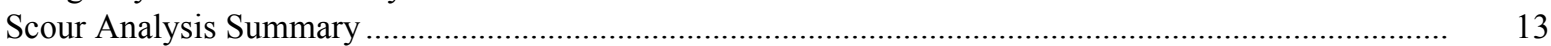

Special Conditions or Assumptions Made in Scour Analysis ...................................................... 13

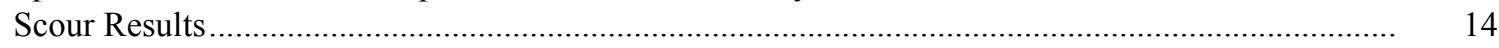

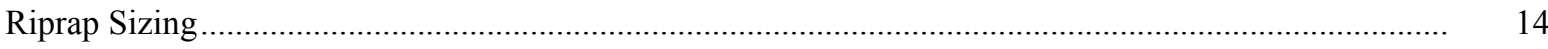

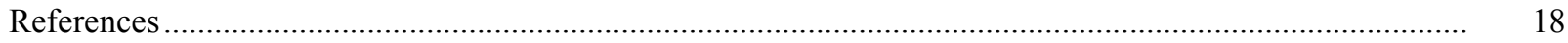

Appendixes:

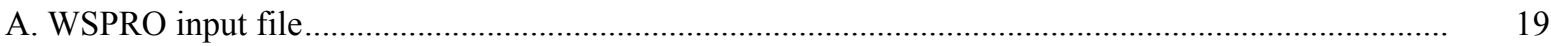

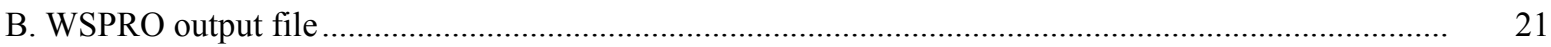

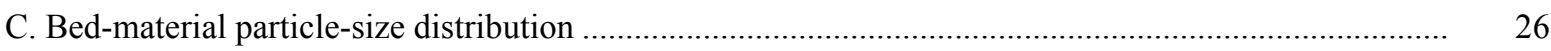

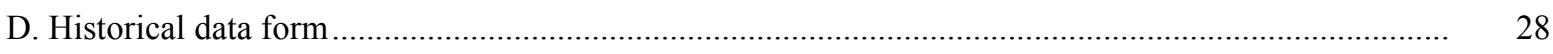

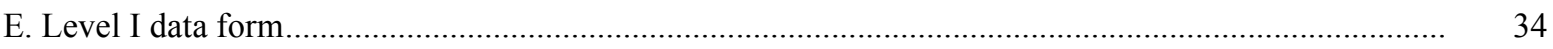

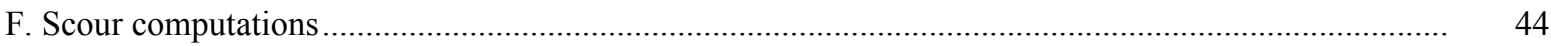

\section{FIGURES}

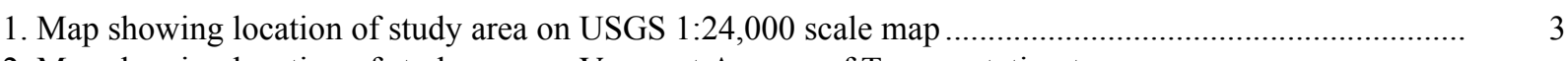

2. Map showing location of study area on Vermont Agency of Transportation town

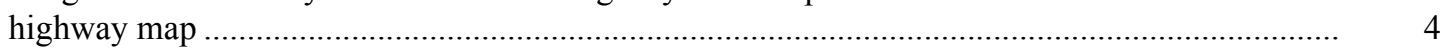

3. Structure FERRUS00070137 viewed from upstream (July 1, 1996).................................................... 5

4. Downstream channel viewed from structure FERRUS00070137 (July 1, 1996)................................. 5

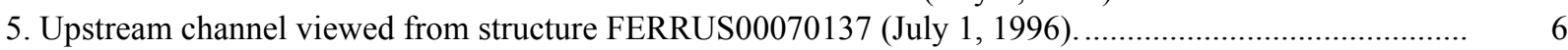

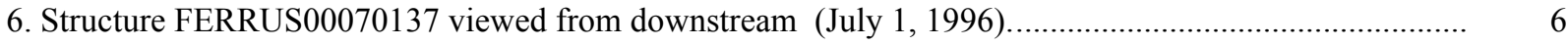

7. Water-surface profiles for the 100- and 500-year discharges at structure FERRUS00070137 on U.S. Route 7, crossing Little Otter Creek,

Ferrisburg, Vermont.

8. Scour elevations for the 100- and 500-year discharges at structure FERRUS00070137 on U.S. Route 7, crossing Little Otter Creek,

Ferrisburg, Vermont.

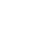

5

6

(
15

\section{TABLES}

1. Remaining footing/pile depth at abutments for the 100-year discharge at structure

FERRUS00070137 on U.S. Route 7, crossing Little Otter Creek,

Ferrisburg, Vermont.

2. Remaining footing/pile depth at abutments for the 500-year discharge at structure

FERRUS00070137 on U.S. Route 7, crossing Little Otter Creek,

Ferrisburg, Vermont... 


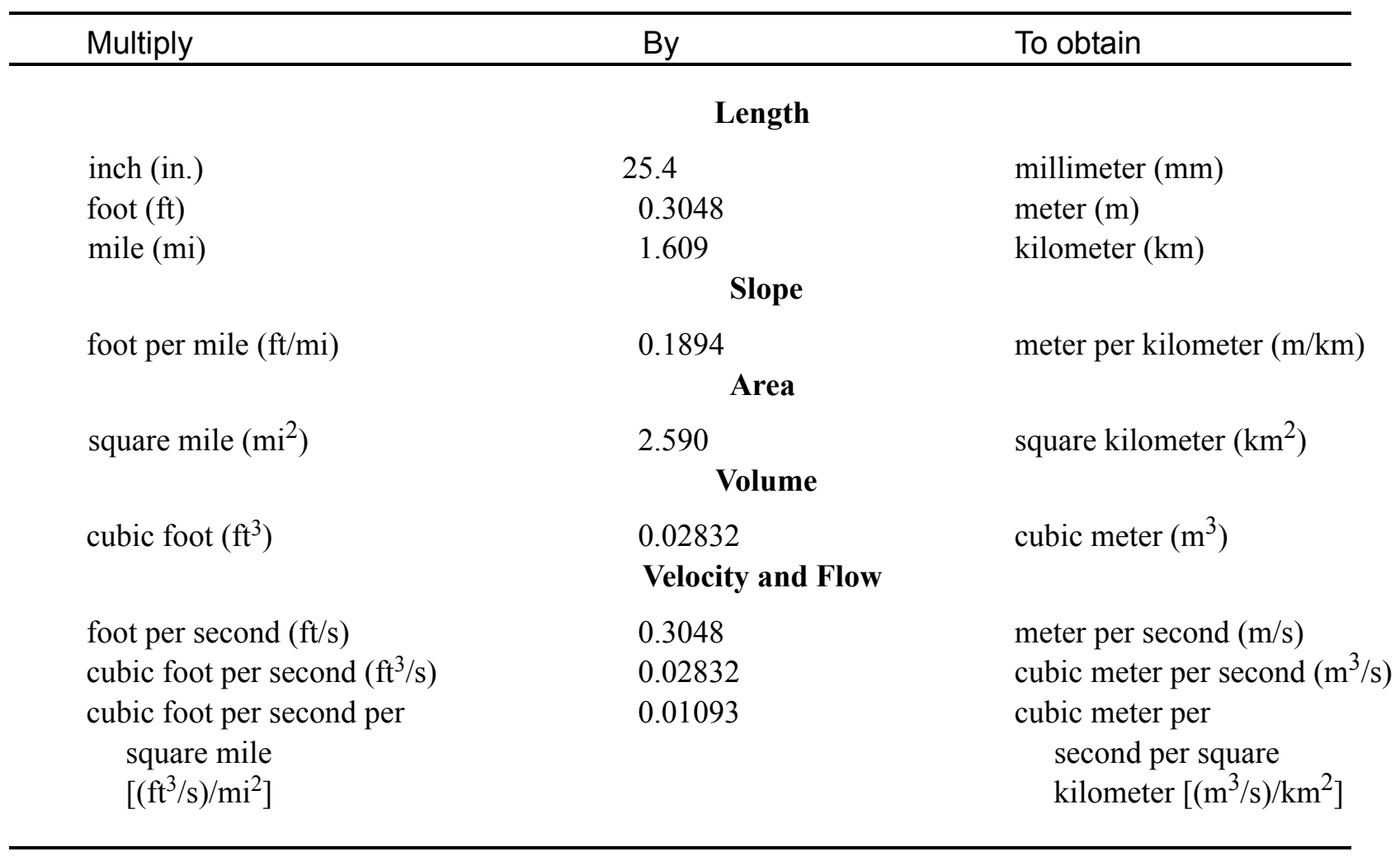

\section{OTHER ABBREVIATIONS}

$\begin{array}{lrlr}\mathrm{BF} & \text { bank full } & \text { LWW } & \text { left wingwall } \\ \mathrm{cfs} & \text { cubic feet per second } & \text { MC } & \text { main channel } \\ \mathrm{D}_{50} & \text { median diameter of bed material } & \text { RAB } & \text { right abutment } \\ \mathrm{DS} & \text { downstream } & \text { RABUT } & \text { face of right abutment } \\ \mathrm{elev} & \text { elevation } & \text { RB } & \text { right bank } \\ \mathrm{f} / \mathrm{p} & \text { flood plain } & \text { ROB } & \text { right overbank } \\ \mathrm{ft}^{2} & \text { square feet } & \text { RWW } & \text { right wingwall } \\ \mathrm{ft} / \mathrm{ft} & \text { feet per foot } & \text { TH } & \text { town highway } \\ \mathrm{JCT} & \text { junction } & \text { UB } & \text { under bridge } \\ \mathrm{LAB} & \text { left abutment } & \text { US } & \text { upstream } \\ \mathrm{LABUT} & \text { face of left abutment } & \text { USGS } & \text { United States Geological Survey } \\ \mathrm{LB} & \text { left bank } & \text { VTAOT Vermont Agency of Transportation } \\ \mathrm{LOB} & \text { left overbank } & \text { WSPRO } & \text { water-surface profile model }\end{array}$

In this report, the words "right" and "left" refer to directions that would be reported by an observer facing downstream. Sea level: In this report, "sea level" refers to the National Geodetic Vertical Datum of 1929-- a geodetic datum derived from a general adjustment of the first-order level nets of the United States and Canada, formerly called Sea Level Datum of 1929.

In the appendices, the above abbreviations may be combined. For example, USLB would represent upstream left bank. 


\title{
LEVEL II SCOUR ANALYSIS FOR BRIDGE 137 (FERRUS00070137) ON U.S. ROUTE 7, CROSSING LITTLE OTTER CREEK, FERRISBURG, VERMONT
}

\author{
By Erick M. Boehmler and Ronda L. Burns
}

\section{INTRODUCTION AND SUMMARY OF RESULTS}

This report provides the results of a detailed Level II analysis of scour potential at structure FERRUS00070137 on U.S. Route 7 crossing Little Otter Creek, Ferrisburg, Vermont (figures 1-8). A Level II study is a basic engineering analysis of the site, including a quantitative analysis of stream stability and scour (U.S. Department of Transportation, 1993). Results of a Level I scour investigation also are included in Appendix E of this report. A Level I investigation provides a qualitative geomorphic characterization of the study site. Information on the bridge, gleaned from Vermont Agency of Transportation (VTAOT) files, was compiled prior to conducting Level I and Level II analyses and is found in Appendix D.

The site is in the Champlain section of the St. Lawrence Valley physiographic province in northwestern Vermont. The $56.7-\mathrm{mi}^{2}$ drainage area is in a predominantly rural and forested basin with some pasture on the valley bottom. In the vicinity of the study site, the surface cover consists of pasture upstream of the bridge. Downstream of the bridge the surface cover consists of trees, shrubs, and grass.

In the study area, Little Otter Creek has a meandering channel with a slope of approximately $0.007 \mathrm{ft} / \mathrm{ft}$, an average channel top width of $86 \mathrm{ft}$ and an average channel depth of $3 \mathrm{ft}$. The predominant channel bed materials are cobbles and gravel with a median grain size $\left(\mathrm{D}_{50}\right)$ of $54.9 \mathrm{~mm}(0.180 \mathrm{ft})$. The geomorphic assessment at the time of the Level I and Level II site visit on July 1, 1996, indicated that the reach was laterally unstable.

The U.S. Route 7 crossing of Little Otter Creek is a 157-ft-long, two-lane bridge consisting of three steel-beam spans (Vermont Agency of Transportation, written communication, December 12,1995). The bridge is supported by vertical, concrete abutment walls with spill-through embankments in front of each abutment wall and two solid concrete piers. The channel is skewed approximately 15 degrees to the opening while the opening-skew-toroadway is zero degrees. 
The scour protection measures at the site consist of type- 3 stone fill (less than 48 inches diameter) on the banks upstream and downstream of the bridge and the lower half of the spill-through embankment slopes on each abutment. Type-1 stone fill (less than 12 inches diameter) protects the upper half of the spill-through embankments and each roadway embankment. Additional details describing conditions at the site are included in the Level II Summary and Appendices D and E.

Scour depths and rock rip-rap sizes were computed using the general guidelines described in Hydraulic Engineering Circular 18 (Richardson and others, 1995). Total scour at a highway crossing is comprised of three components: 1) long-term streambed degradation; 2) contraction scour (due to accelerated flow caused by a reduction in flow area at a bridge) and; 3) local scour (caused by accelerated flow around piers and abutments). Total scour is the sum of the three components. Equations are available to compute depths for contraction and local scour and a summary of the results of these computations follows.

Contraction scour for all modelled flows ranged from 1.8 to $2.3 \mathrm{ft}$. The worst-case contraction scour occurred at the 500-year discharge. Abutment scour ranged from 10.4 to $14.9 \mathrm{ft}$. The worst-case abutment scour occurred at the 500-year discharge. There are two piers for which computed pier scour ranged from 7.5 to $13.4 \mathrm{ft}$. The left and right piers in this report are presented as pier 1 and pier 2 respectively. The worst-case pier scour occurred at pier 1 for the 500-year discharge. Additional information on scour depths and depths to armoring are included in the section titled "Scour Results". Scoured-streambed elevations, based on the calculated scour depths, are presented in tables 1 and 2. A crosssection of the scour computed at the bridge is presented in figure 8. Scour depths were calculated assuming an infinite depth of erosive material and a homogeneous particle-size distribution.

It is generally accepted that the Froehlich equation (abutment scour) gives "excessively conservative estimates of scour depths" (Richardson and others, 1995, p. 47). Usually, computed scour depths are evaluated in combination with other information including (but not limited to) historical performance during flood events, the geomorphic stability assessment, existing scour protection measures, and the results of the hydraulic analyses. Therefore, scour depths adopted by VTAOT may differ from the computed values documented herein. 


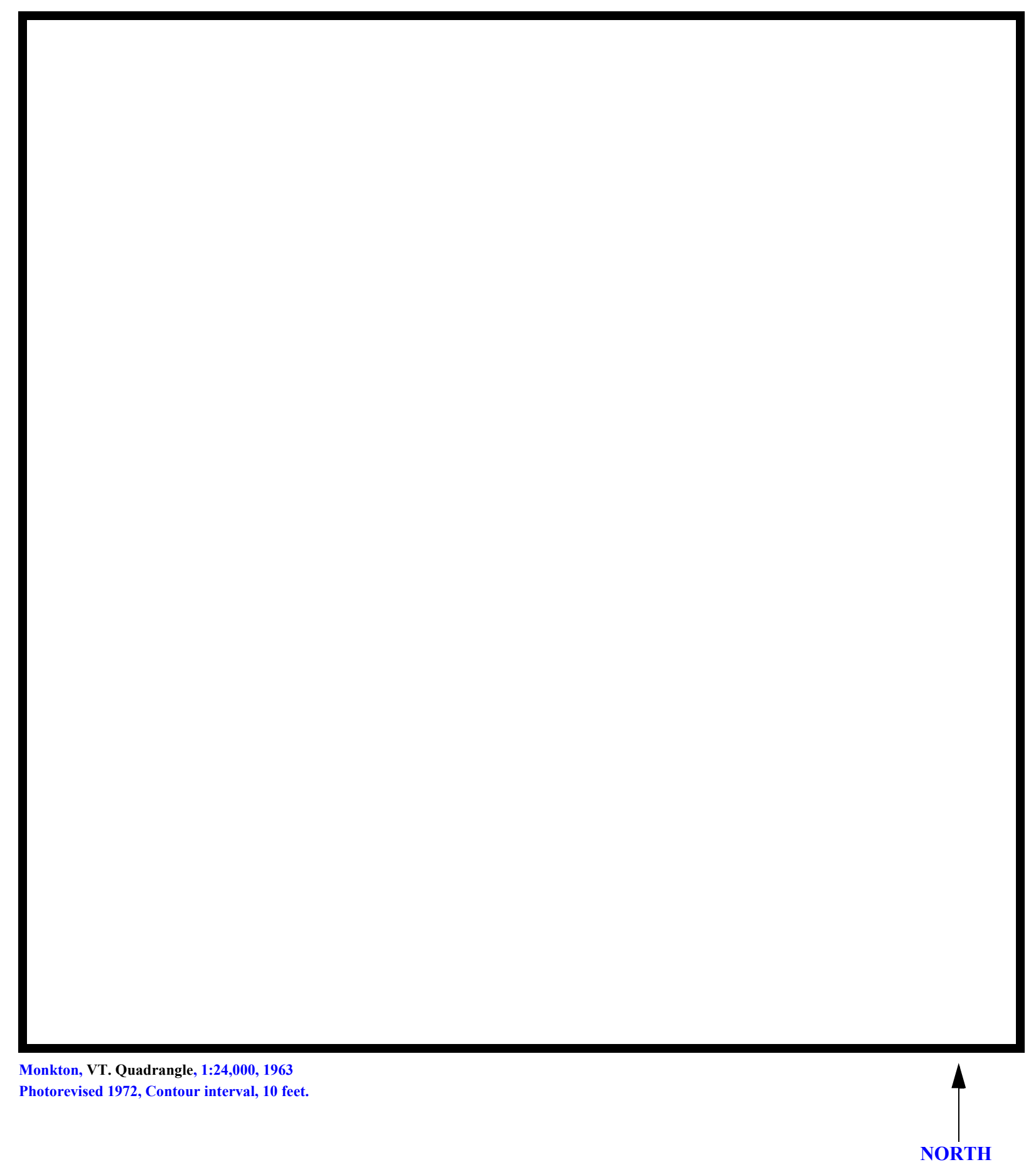

Figure 1. Location of study area on USGS 1:24,000 scale map. 
Figure 2. Location of study area on Vermont Agency of Transportation town highway map. 

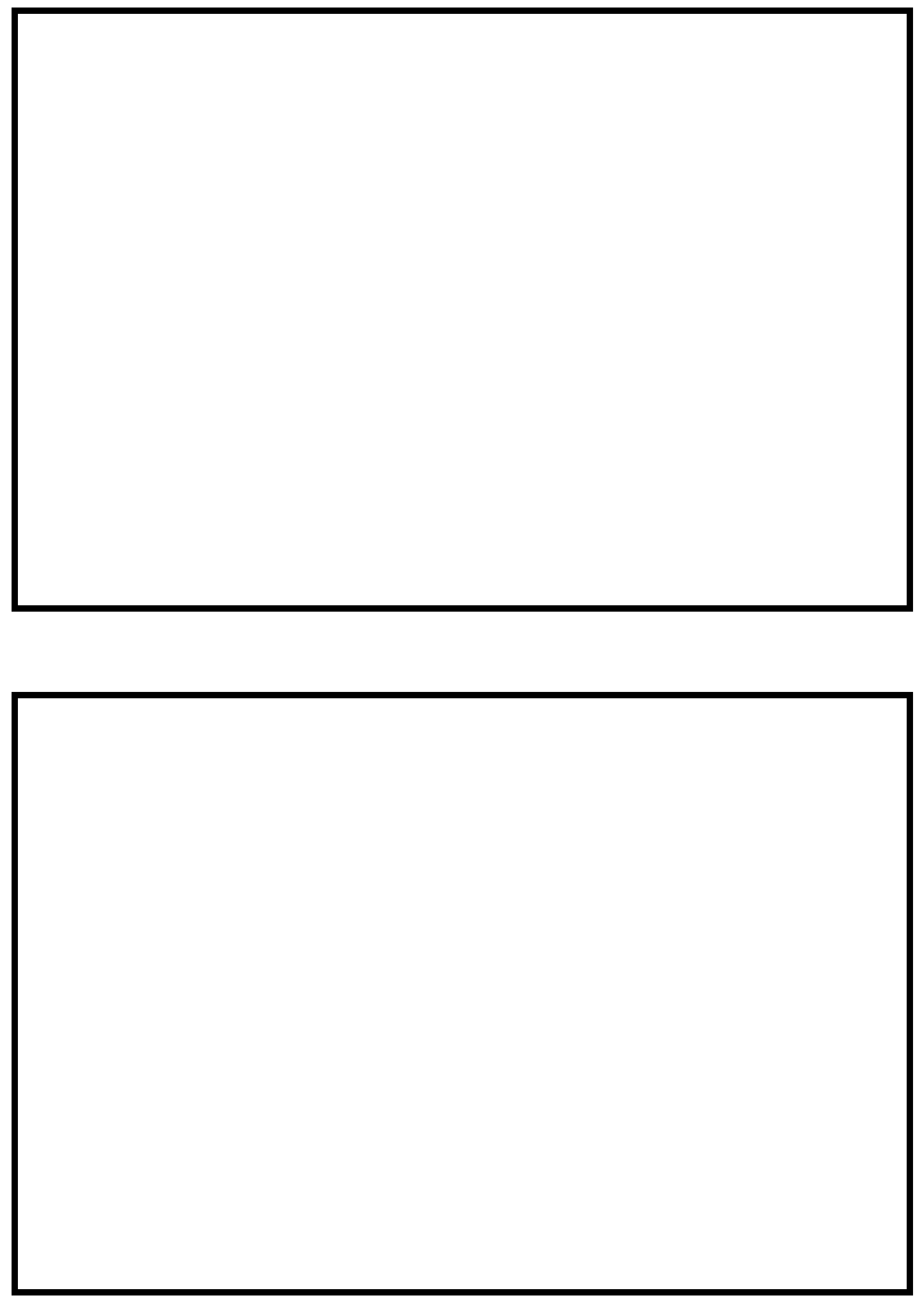

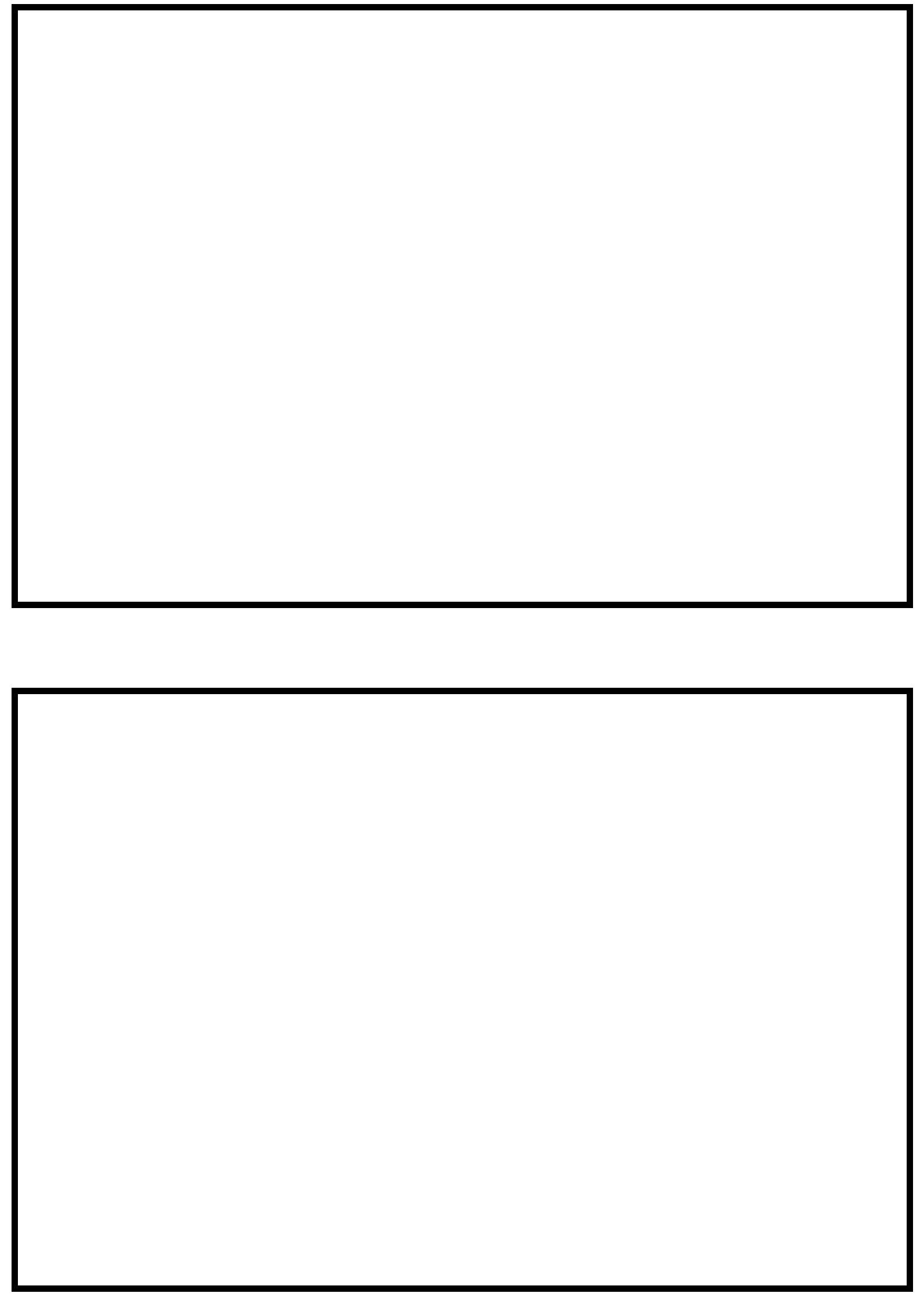


\section{LEVEL II SUMMARY}

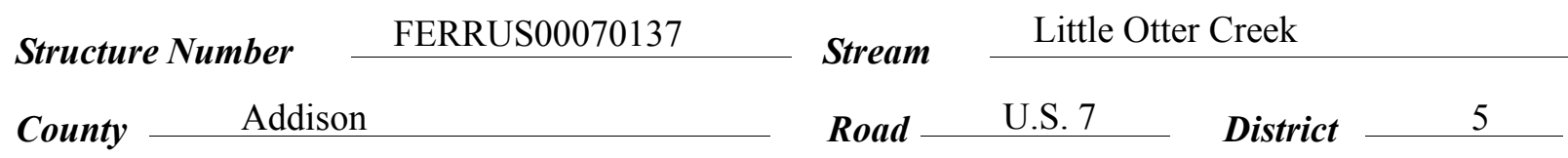

\section{Description of Bridge}

Bridge length $\frac{157}{f t} \quad$ Bridge width $\frac{35.0}{f t}$ Max span length $\stackrel{57}{f t}$ Alignment of bridge to road (on curve or straight) Spill-through Abutment type

Stone fill on abutment? Straight

namanimsinu af ata... n fill Type-3 on the lower half of each spill-through embankment and TypeSloping $7 / 1 / 96$ 1 on the upper half. Type-3 stone fill protection is present on the banks upstream and downstream of the bridge.

Abutments and piers are concrete. There are spillthrough embankments in front of each abutment wall.

\section{Y}

Is bridge skewed to flood flow according to Yes ' survey? Angle

The valley is straight but the channel meanders across the valley bottom, The spill-through embankment on the left abutment blocks the left side of the channel.

Debris accumulation on bridge at time of Level I or Level II site visit:

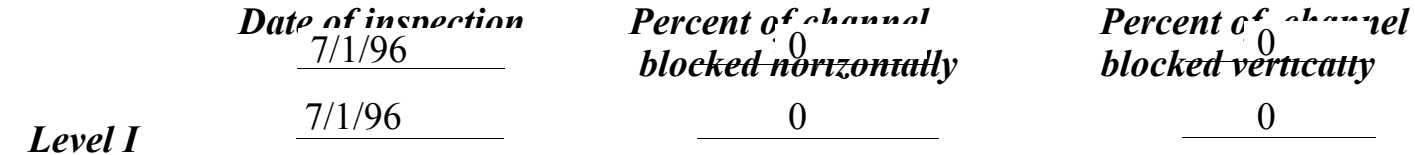

Level II

Low. Although the banks are unstable, there are few trees on the banks upstream.

Potential for debris

None evident on 7/1/96.

Doscriho anv, fonturos noar ar at tho hridoo that mav, affort flou, (includo ahsorvation dato) 


\section{Description of the Geomorphic Setting}

General topography The channel is located in a low relief valley setting with narrow overbanks and moderately sloping valley walls on both sides.

Geomorphic conditions at bridge site: downstream (DS), upstream (US)

Date of inspection $\quad 7 / 1 / 96$

DS left: $\quad$ Slightly sloping channel bank to a narrow overbank.

DS right: Slightly sloping channel bank to a narrow overbank.

US left: $\quad$ Slightly sloping channel bank to valley wall.

US right: $\quad$ Slightly sloping channel bank to a narrow overbank.

\section{Description of the Channel}

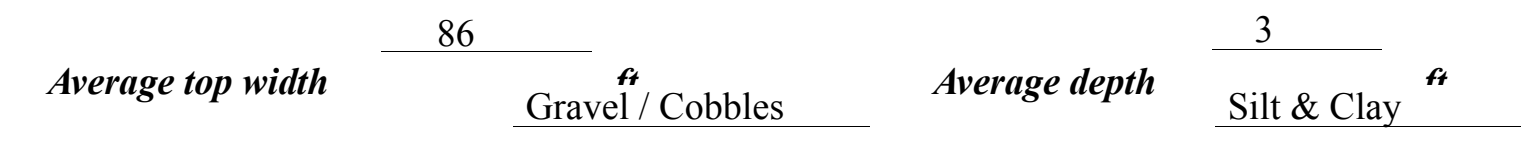

Predominant bed material

Bank material

Meandering and

laterally unstable with alluvial channel boundaries.

$7 / 1 / 96$

Vegetative co 1 Trees with some shrubs and brush.

DS left: $\quad$ Trees with some shrubs and brush.

DS right: Grass with a few trees.

US left: $\quad$ Grass.

US right: $\quad$ No

Do banks appear stable? On 7/1/96 there, was, a cut-bank noted on the upstream right bank. A dateck of bank material has slumped down and away from the bank.

None evident on

$7 / 1 / 96$

Describe any obstructions in channel and date of observation. 


\section{Hydrology}

Drainage area $\quad \frac{56.7}{m i^{2}}$

Percentage of drainage area in physiographic provinces: (approximate)

Physiographic province/section

St. Lawrence Valley / Champlain
Percent of drainage area 100

Is drainage area considered rural or urban? — Rural _ Describe any significant urbanization:

Yes

Is there a USGS gage on the stream of interest? Little Otter Creek at Ferrisburg, VT USGS gage description 04282650

USGS gage number 57.1

Gage drainage area $\quad \mathrm{mi}^{2}$ No

Is there a lake/p

. ... . . . . . . . . . .

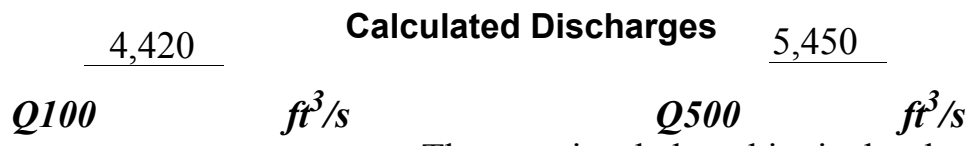

The gage just below this site has less than 7 years of

record. Hence, the record was not considered in the selection of the 100- and 500-year discharges for this analysis. The discharges are based on discharge frequency curves computed by use of several empirical equations (Benson, 1962; FHWA, 1983; Johnson and Tasker, 1974; Potter, 1957a\&b; and Talbot, 1887). The median of the 100- and 500-year discharges from each empirical discharge frequency curve were selected for the hydraulic analysis at this site. 


\section{Description of the Water-Surface Profile Model (WSPRO) Analysis}

Datum for WSPRO analysis (USGS survey, sea level, VTAOT plans)

USGS survey

Datum tie between USGS survey and VTAOT plans

Subtract 321.4 feet from the

USGS survey to obtain VTAOT plans' datum.

Description of reference marks used to determine USGS datum. $\quad$ RM1 is a one half inch

bolt on top of the stream gage orifice pier (elev. $470.76 \mathrm{ft}$, arbitrary survey datum). RM2 is a

brass tablet engraved "VT Hwy Dept. 1959" on top of the concrete curb at the upstream left

corner of the bridge deck (elev. $500.54 \mathrm{ft}$, arbitrary survey datum).

\section{Cross-Sections Used in WSPRO Analysis}

\begin{tabular}{|c|c|c|c|}
\hline${ }^{1}$ Cross-section & $\begin{array}{c}\text { Section } \\
\text { Reference } \\
\text { Distance } \\
\text { (SRD) in feet }\end{array}$ & $\begin{array}{c}{ }^{2} \text { Cross-section } \\
\text { development }\end{array}$ & Comments \\
\hline EXITX & -152 & 1 & Exit section \\
\hline FULLV & 0 & 2 & $\begin{array}{l}\text { Downstream Full-valley } \\
\text { section (Templated from } \\
\text { EXITX) }\end{array}$ \\
\hline BRIDG & 0 & 1 & Bridge section \\
\hline RDWAY & 18 & 1 & Road Grade section \\
\hline APPRO & 102 & 2 & $\begin{array}{l}\text { Modelled Approach sec- } \\
\text { tion (Templated from } \\
\text { APTEM) }\end{array}$ \\
\hline APTEM & 189 & 1 & $\begin{array}{l}\text { Approach section as sur- } \\
\text { veyed (Used as a tem- } \\
\text { plate) }\end{array}$ \\
\hline
\end{tabular}

${ }^{1}$ For location of cross-sections see plan-view sketch included with Level I field form, Appendix E.

For more detail on how cross-sections were developed see WSPRO input file. 


\section{Data and Assumptions Used in WSPRO Model}

Hydraulic analyses of the reach were done by use of the Federal Highway Administration's WSPRO step-backwater computer program (Shearman and others, 1986, and Shearman, 1990). The analyses reported herein reflect conditions existing at the site at the time of the study. Furthermore, in the development of the model it was necessary to assume no accumulation of debris or ice at the site. Results of the hydraulic model are presented in the Bridge Hydraulic Summary, Appendix B, and figure 7.

Channel roughness factors (Manning's " $n$ ") used in the hydraulic model were estimated using field inspections at each cross section following the general guidelines described by Arcement and Schneider (1989). Final adjustments to the values were made during the modelling of the reach. Channel " $n$ " values for the reach ranged from 0.040 to 0.044 , and overbank "n" values were 0.040 .

The starting water surface at the exit section (EXITX) for each flow modeled was estimated by use of the rating curve for the gage, extrapolated to the 500-year discharge.

The surveyed approach section (APTEM) was moved along the approach channel slope $(0.00397 \mathrm{ft} / \mathrm{ft})$ to establish the modelled approach section (APPRO), one bridge length upstream

of the upstream face as recommended by Shearman and others (1986). This approach also provides a consistent method for determining scour variables.

For the 500-year discharge, WSPRO assumes critical depth at the bridge section. A supercritical model was developed for this discharge. After analyzing both the supercritical and subcritical profiles, it was determined that the water surface profile passes through critical depth within the bridge opening. Thus, the assumption of critical depth at the bridge is a satisfactory solution. 


\section{Bridge Hydraulics Summary}

$\begin{array}{llll}\text { Average bridge embankment elevation } & 501.2 & f t \\ \text { Average low steel elevation } & 497.3 & \boldsymbol{f t}\end{array}$

100-year discharge $\quad 4,420 \quad \mathrm{ft}^{3} / \mathrm{s}$

Water-surface elevation in bridge opening $\quad \begin{array}{lll}474.8 \quad f t \\ \end{array}$

Road overtopping? ___ No Discharge over road ___ --,$i^{3} / s$

Area of flow in bridge opening $\quad 349 \quad \mathrm{ft}^{2}$

Average velocity in bridge opening $12.7 \quad \mathrm{ft} / \mathrm{s}$

Maximum WSPRO tube velocity at bridge $14.8 \mathrm{ft} / \mathrm{s}$

Water-surface elevation at Approach section with bridge 478.8

Water-surface elevation at Approach section without bridge $\quad \overline{476.6}$

Amount of backwater caused by bridge

2.2 it

500-year discharge $\quad 5,450 \quad \mathrm{ft}^{3} / \mathrm{s}$

Water-surface elevation in bridge opening $\quad 475.7$ ft

Road overtopping? ___ No Discharge over road ___ --,$i^{3} / \mathrm{s}$

Area of flow in bridge opening $\quad 407 \quad \mathrm{ft}^{2}$

Average velocity in bridge opening $13.4 \mathrm{ft} / \mathrm{s}$

Maximum WSPRO tube velocity at bridge 15.9 , 's

Water-surface elevation at Approach section with bridge 480.1

Water-surface elevation at Approach section without bridge $\quad 477.3$

Amount of backwater caused by bridge 2.8 .

Incipient overtopping discharge ___ -- $f^{3} / \mathrm{s}$

Water-surface elevation in bridge opening $\quad--\quad t$

Area of flow in bridge opening _ $\quad--\quad \mathrm{ft}^{2}$

Average velocity in bridge opening ___ $\quad \mathrm{ft} / \mathrm{s}$

Maximum WSPRO tube velocity at bridge _-- $\mathrm{ft} / \mathrm{s}$

Water-surface elevation at Approach section with bridge

Water-surface elevation at Approach section without bridge

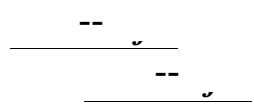

Amount of backwater caused by bridge _ 


\section{Scour Analysis Summary}

\section{Special Conditions or Assumptions Made in Scour Analysis}

Scour depths were computed using the general guidelines described in Hydraulic Engineering Circular 18 (Richardson and others, 1995). Scour depths were calculated assuming an infinite depth of erosive material and a homogeneous particle-size distribution. The results of the scour analysis are presented in tables 1 and 2 and a graph of the scour depths is presented in figure 8 .

Contraction scour was computed by use of the clear-water contraction scour equation (Richardson and others, 1995, p. 32, equation 20). For contraction scour computations, the average depth in the contracted section (AREA/TOPWIDTH) is subtracted from the depth of flow computed by the scour equation (Y2) to determine the actual amount of scour. There is no armoring potential.

Abutment scour at the left abutment for each modeled discharge was computed by use of the Froehlich equation (Richardson and others, 1995, p. 48, equation 28). Variables for the Froehlich equation include the Froude number of the flow approaching the embankments, the length of the embankment blocking flow, and the depth of flow approaching the embankment less any roadway overtopping.

Scour at the right abutment for each modeled discharge was computed by use of the HIRE equation (Richardson and others, 1995, p. 49, equation 29) because the HIRE equation is recommended when the length to depth ratio of the embankment blocking flow exceeds 25. The variables used by the HIRE abutment-scour equation are defined the same as those defined for the Froehlich abutment-scour equation.

Because the influence of scour processes on the spill-through embankment material is uncertain, the scour depth at the vertical concrete abutment walls is unknown. Therefore, scour depths were applied for the entire spill-through embankment below the elevation at the toe of each embankment, as shown in

figure 8. At the toe of the left abutment spill-through embankment, the maximum scour depth between pier 1 and the left abutment was shown in figure 8. However, the computed scour depth at pier 1 did not result in an elevation below the bottom of the footing.

Pier scour was computed by use of an equation developed at Colorado State University (Richardson and others, 1995, p. 36, equation 21) for all discharges modeled. Variables for the pier scour equation include pier length, pier width, average depth and maximum velocity (for the froude number) immediately upstream of the bridge, and four correction factors for pier shape, flow attack angle, streambed-form, and streambed armoring. 


\section{Scour Results}

\section{0-yr discharge 500-yr discharge}

Contraction scour:

(Scour depths in feet)

Main channel

Live-bed scour

Clear-water scour

Depth to armoring

Left overbank

Right overbank

Local scour:

Abutment scour

14.2

14.9

Left abutment

10.4

$12.6-$

Right abutment

Pier scour

Pier 1

7.5

7.9

12.7

Pier 2

Pier 3

\section{Abutments:}

Left abutment

Right abutment

Piers:

Pier 1

Pier 2

\section{Riprap Sizing}

Incipient overtopping 100-yrdischarge 500-yrdischarge discharge

2.3

2.3

$2.4^{-}$

2.4

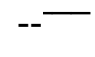

overtopping discharge
Incipient 


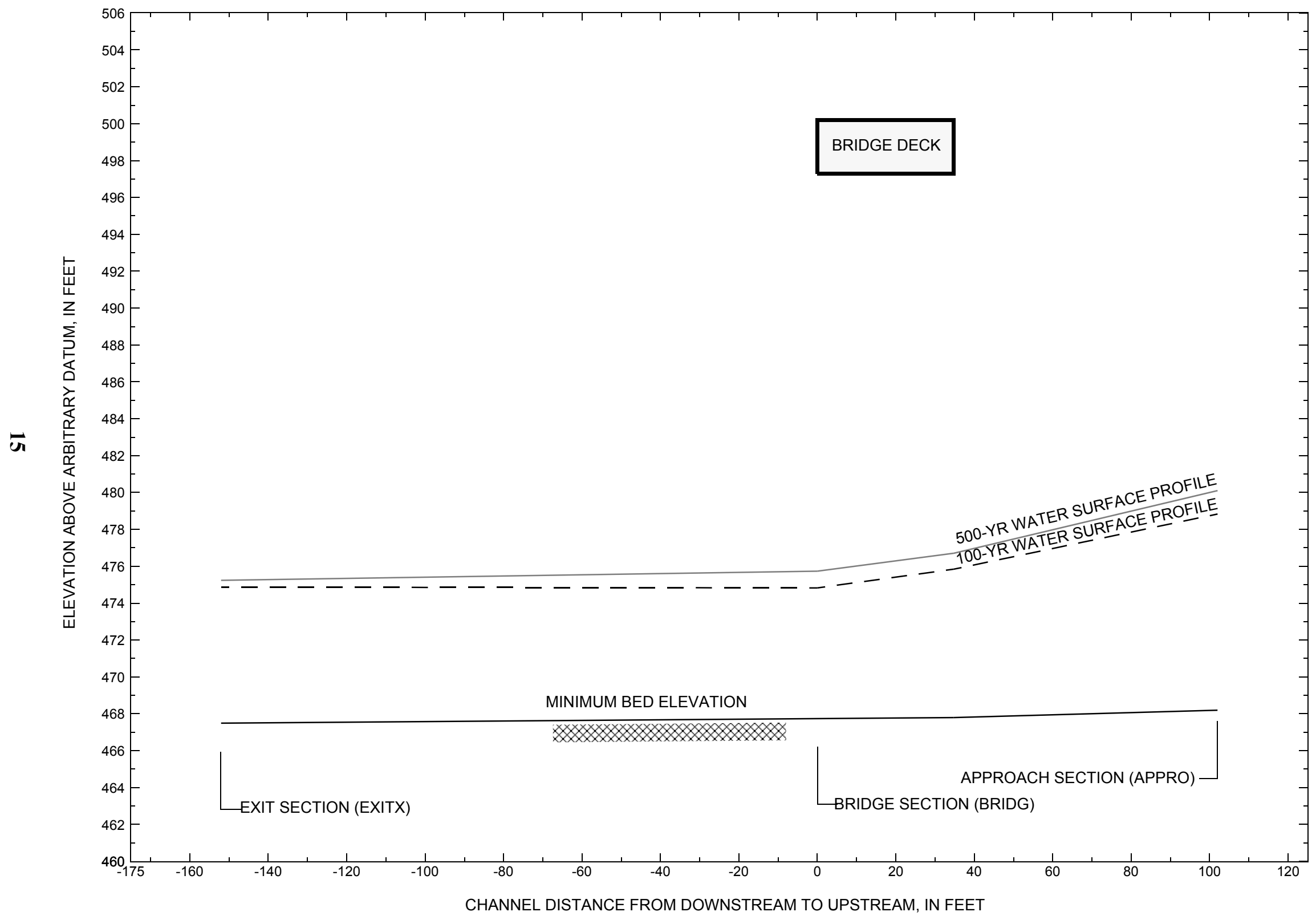

Figure 7. Water-surface profiles for the 100- and 500-yr discharges at structure FERRUS00070137 on U.S. Route 7, crossing Little Otter Creek, Ferrisburg, Vermont. 


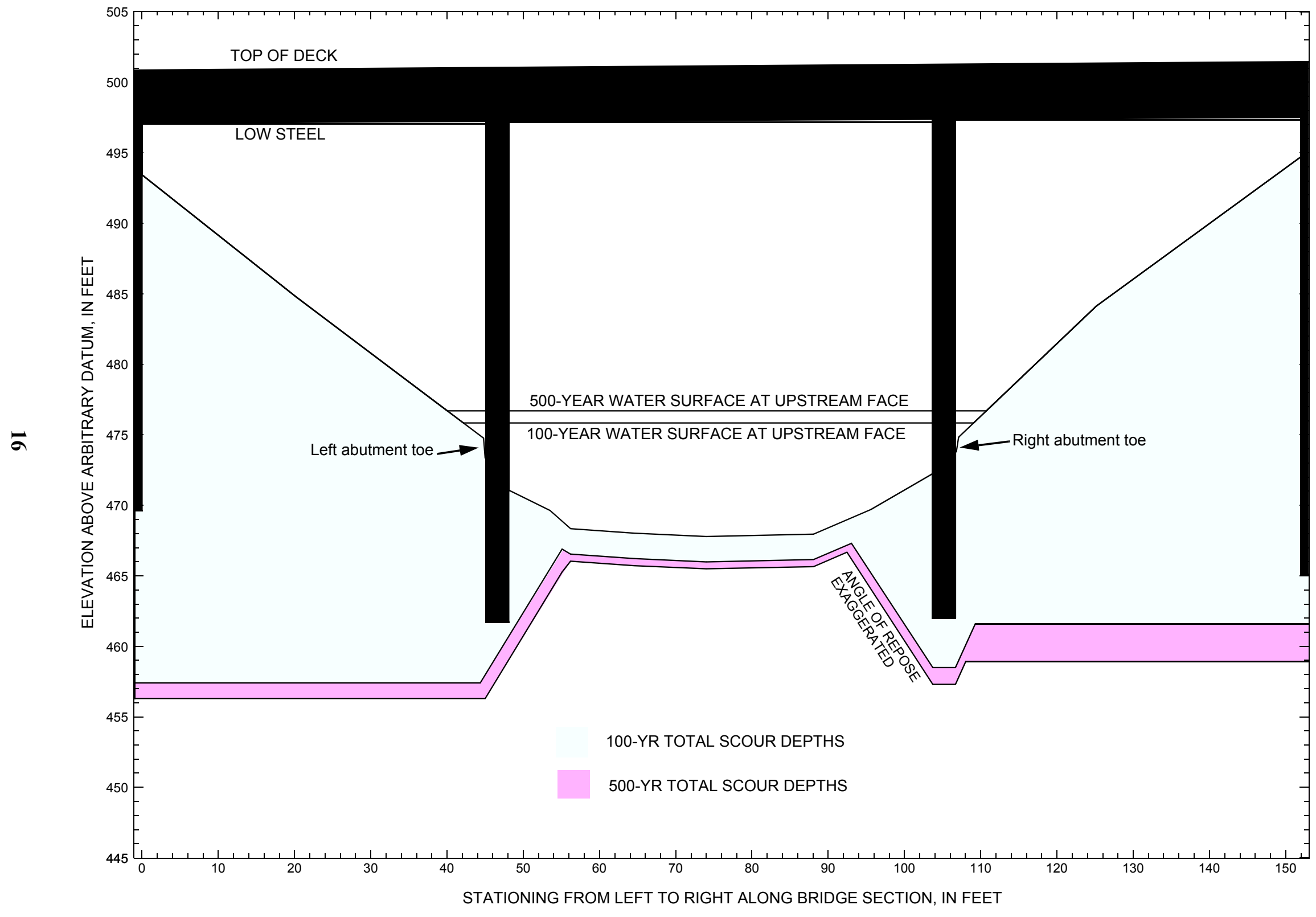

Figure 8. Scour elevations for the 100-yr and 500-yr discharges at structure FERRUS00070137 on U.S. Route 7, crossing Little Otter Creek, Ferrisburg, Vermont. 
Table 1. Remaining footing/pile depth at abutments for the 100-year discharge at structure FERRUS00070137 on U.S. Route 7, crossing Little Otter Creek, Ferrisburg, Vermont.

[VTAOT, Vermont Agency of Transportation; --,no data]

\begin{tabular}{|c|c|c|c|c|c|c|c|c|c|c|c|}
\hline Description & Station $^{1}$ & $\begin{array}{c}\text { VTAOT } \\
\text { Bridge seat } \\
\text { elevation } \\
\text { (feet) }\end{array}$ & $\begin{array}{c}\text { Surveyed } \\
\text { Bridge seat } \\
\text { elevation }^{2} \\
\text { (feet) }\end{array}$ & $\begin{array}{l}\text { Bottom of } \\
\text { footing } \\
\text { elevation } \\
\text { (feet) }\end{array}$ & $\begin{array}{c}\text { Channel } \\
\text { elevation at } \\
\text { abutment/ } \\
\text { pier }^{2} \\
\text { (feet) }\end{array}$ & $\begin{array}{l}\text { Contraction } \\
\text { scour depth } \\
\text { (feet) }\end{array}$ & $\begin{array}{l}\text { Abutment } \\
\text { scour } \\
\text { depth } \\
\text { (feet) }\end{array}$ & $\begin{array}{l}\text { Pier } \\
\text { scour } \\
\text { depth } \\
\text { (feet) }\end{array}$ & $\begin{array}{l}\text { Depth of } \\
\text { total scour } \\
\text { (feet) }\end{array}$ & $\begin{array}{c}\text { Elevation of } \\
\text { scour }^{2} \\
\text { (feet) }\end{array}$ & $\begin{array}{c}\text { Remaining } \\
\text { footing/pile } \\
\text { depth } \\
\text { (feet) }\end{array}$ \\
\hline \multicolumn{12}{|c|}{100 -yr. discharge is 4,420 cubic-feet per second } \\
\hline Left abutment & 0.0 & 175.4 & 496.7 & 469.6 & 493.4 & -- & -- & -- & -- & -- & -12.2 \\
\hline Left abutment toe & 45.1 & -- & -- & -- & 473.4 & 1.8 & 14.2 & -- & 16.0 & 457.4 & -- \\
\hline Pier 1 & 46.6 & 175.5 & -- & 461.7 & 472.2 & 1.8 & -- & 7.5 & 9.3 & 462.9 & 1.2 \\
\hline Pier 2 & 105.2 & 175.7 & -- & 461.9 & 473.0 & 1.8 & -- & 12.7 & 14.5 & 458.5 & -3.5 \\
\hline Right abutment toe & 106.7 & -- & -- & -- & 473.8 & 1.8 & 10.4 & -- & 12.2 & 461.6 & -- \\
\hline Right abutment & 152.0 & 175.9 & 497.2 & 465.1 & 494.7 & -- & -- & -- & -- & -- & -3.5 \\
\hline
\end{tabular}

1.Measured along the face of the most constricting side of the bridge.

2.Arbitrary datum for this study.

Table 2. Remaining footing/pile depth at abutments for the 500-year discharge at structure FERRUS00070137 on U.S. Route 7, crossing Little Otter Creek, Ferrisburg, Vermont.

[VTAOT, Vermont Agency of Transportation; --, no data]

\begin{tabular}{|c|c|c|c|c|c|c|c|c|c|c|c|}
\hline Description & Station $^{1}$ & $\begin{array}{c}\text { VTAOT } \\
\text { Bridge seat } \\
\text { elevation } \\
\text { (feet) }\end{array}$ & $\begin{array}{c}\text { Surveyed } \\
\text { Bridge seat } \\
\text { elevation }^{2} \\
\text { (feet) }\end{array}$ & $\begin{array}{l}\text { Bottom of } \\
\text { footing } \\
\text { elevation } \\
\text { (feet) }\end{array}$ & $\begin{array}{c}\text { Channel } \\
\text { elevation at } \\
\text { abutment/ } \\
\text { pier }^{2} \\
\text { (feet) }\end{array}$ & $\begin{array}{l}\text { Contraction } \\
\text { scour depth } \\
\text { (feet) }\end{array}$ & $\begin{array}{l}\text { Abutment } \\
\text { scour } \\
\text { depth } \\
\text { (feet) }\end{array}$ & $\begin{array}{l}\text { Pier } \\
\text { scour } \\
\text { depth } \\
\text { (feet) }\end{array}$ & $\begin{array}{l}\text { Depth of } \\
\text { total scour } \\
\text { (feet) }\end{array}$ & $\begin{array}{c}\text { Elevation of } \\
\text { scour }^{2} \\
\text { (feet) }\end{array}$ & $\begin{array}{c}\text { Remaining } \\
\text { footing/pile } \\
\text { depth } \\
\text { (feet) }\end{array}$ \\
\hline \multicolumn{12}{|c|}{500 -yr. discharge is 5,450 cubic-feet per second } \\
\hline Left abutment & 0.0 & 175.4 & 496.7 & 469.6 & 493.4 & -- & -- & -- & -- & -- & -13.4 \\
\hline Left abutment toe & 45.1 & -- & -- & -- & 473.4 & 2.3 & 14.9 & -- & 17.2 & 456.2 & -- \\
\hline Pier 1 & 46.6 & 175.5 & -- & 461.7 & 472.2 & 2.3 & -- & 7.9 & 10.2 & 462.0 & 0.3 \\
\hline Pier 2 & 105.2 & 175.7 & -- & 461.9 & 473.0 & 2.3 & -- & 13.4 & 15.7 & 457.3 & -4.7 \\
\hline Right abutment toe & 106.7 & -- & -- & -- & 473.8 & 2.3 & 12.6 & -- & 14.9 & 458.9 & -- \\
\hline Right abutment & 152.0 & 175.9 & 497.2 & 465.1 & 494.7 & -- & -- & -- & -- & -- & -6.2 \\
\hline
\end{tabular}

1.Measured along the face of the most constricting side of the bridge.

2.Arbitrary datum for this study. 


\section{SELECTED REFERENCES}

Arcement, G.J., Jr., and Schneider, V.R., 1989, Guide for selecting Manning's roughness coefficients for natural channels and flood plains: U.S. Geological Survey Water-Supply Paper 2339, 38 p.

Barnes, H.H., Jr., 1967, Roughness characteristics of natural channels: U.S. Geological Survey Water-Supply Paper 1849,213 p.

Benson, M. A., 1962, Factors Influencing the Occurrence of Floods in a Humid Region of Diverse Terrain: U.S. Geological Survey WaterSupply Paper 1580-B, 64 p.

Brown, S.A. and Clyde, E.S., 1989, Design of riprap revetment: Federal Highway Administration Hydraulic Engineering Circular No. 11, Publication FHWA-IP-89-016, 156 p.

Federal Highway Administration, 1983, Runoff estimates for small watersheds and development of sound design: Federal Highway Administration Report FHWA-RD-77-158

Froehlich, D.C., 1989, Local scour at bridge abutments in Ports, M.A., ed., Hydraulic Engineering--Proceedings of the 1989 National Conference on Hydraulic Engineering: New York, American Society of Civil Engineers, p. 13-18.

Hayes, D.C.,1993, Site selection and collection of bridge-scour data in Delaware, Maryland, and Virginia: U.S. Geological Survey WaterResources Investigation Report 93-4017, 23 p.

Johnson, C.G. and Tasker, G.D.,1974, Progress report on flood magnitude and frequency of Vermont streams: U.S. Geological Survey OpenFile Report 74-130, 37 p.

Lagasse, P.F., Schall, J.D., Johnson, F., Richardson, E.V., Chang, F., 1995, Stream Stability at Highway Structures: Federal Highway Administration Hydraulic Engineering Circular No. 20, Publication FHWA-IP-90-014, 144 p.

Laursen, E.M., 1960, Scour at bridge crossings: Journal of the Hydraulics Division, American Society of Civil Engineers, v. 86, no. HY2, p. 39-53.

Potter, W. D., 1957a, Peak rates of runoff in the Adirondack, White Mountains, and Maine woods area, Bureau of Public Roads

Potter, W. D., 1957b, Peak rates of runoff in the New England Hill and Lowland area, Bureau of Public Roads

Richardson, E.V. and Davis, S.R., 1995, Evaluating scour at bridges: Federal Highway Administration Hydraulic Engineering Circular No. 18, Publication FHWA-IP-90-017, 204 p.

Richardson, E.V., Simons, D.B., and Julien, P.Y., 1990, Highways in the river environment: Federal Highway Administration Publication FHWA-HI-90-016.

Ritter, D.F., 1984, Process Geomorphology: W.C. Brown Co., Debuque, Iowa, 603 p.

Shearman, J.O., 1990, User's manual for WSPRO--a computer model for water surface profile computations: Federal Highway Administration Publication FHWA-IP-89-027, 187 p.

Shearman, J.O., Kirby, W.H., Schneider, V.R., and Flippo, H.N., 1986, Bridge waterways analysis model; research report: Federal Highway Administration Publication FHWA-RD-86-108, 112 p.

Talbot, A.N., 1887, The determination of water-way for bridges and culverts.

U.S. Department of Transportation, 1993, Stream stability and scour at highway bridges, Participant Workbook: Federal Highway Administration Publication FHWA HI-91-011.

U.S. Geological Survey, 1963, Monkton, Vermont 7.5 Minute Series quadrangle map: U.S. Geological Survey Topographic Maps, Aerial photography, 1961, Contour interval, 10 feet, Scale 1:24,000.

U.S. Geological Survey, 1980, Westport, New York-Vermont 7.5 x 15 Minute Series quadrangle map: U.S. Geological Survey Topographic Maps, Aerial photographs, 1974, Contour interval, 5 meters, Scale 1:25,000. 


\section{APPENDIX A: \\ WSPRO INPUT FILE}




\section{WSPRO INPUT FILE}

*

$Q$ WS

*

XS

GR

GR

GR

GR

$\mathrm{N}$

SA

*

XS

*

BR

GR

GR

GR

GR

GR

*

*

PW 0

PW 0

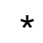

*

CD

$\mathrm{N}$

*

*

XR

GR

GR

GR

*

$\mathrm{XT}$

GR

GR

GR

AS

GT

BP

$\mathrm{N}$

SA
U.S. Geological Survey WSPRO Input File ferr137.wsp Hydraulic analysis for structure FERRUS00070137 Date: 20-NOV-96 U.S. Route 7 Crossing Little Otter Creek, Ferrisburg, VT

$\begin{array}{lllllllllllllllllllll}6 & 29 & 30 & 552 & 553 & 551 & 5 & 16 & 17 & 13 & 3 & * & 15 & 14 & 23 & 21 & 11 & 12 & 4 & 7 & 3\end{array}$

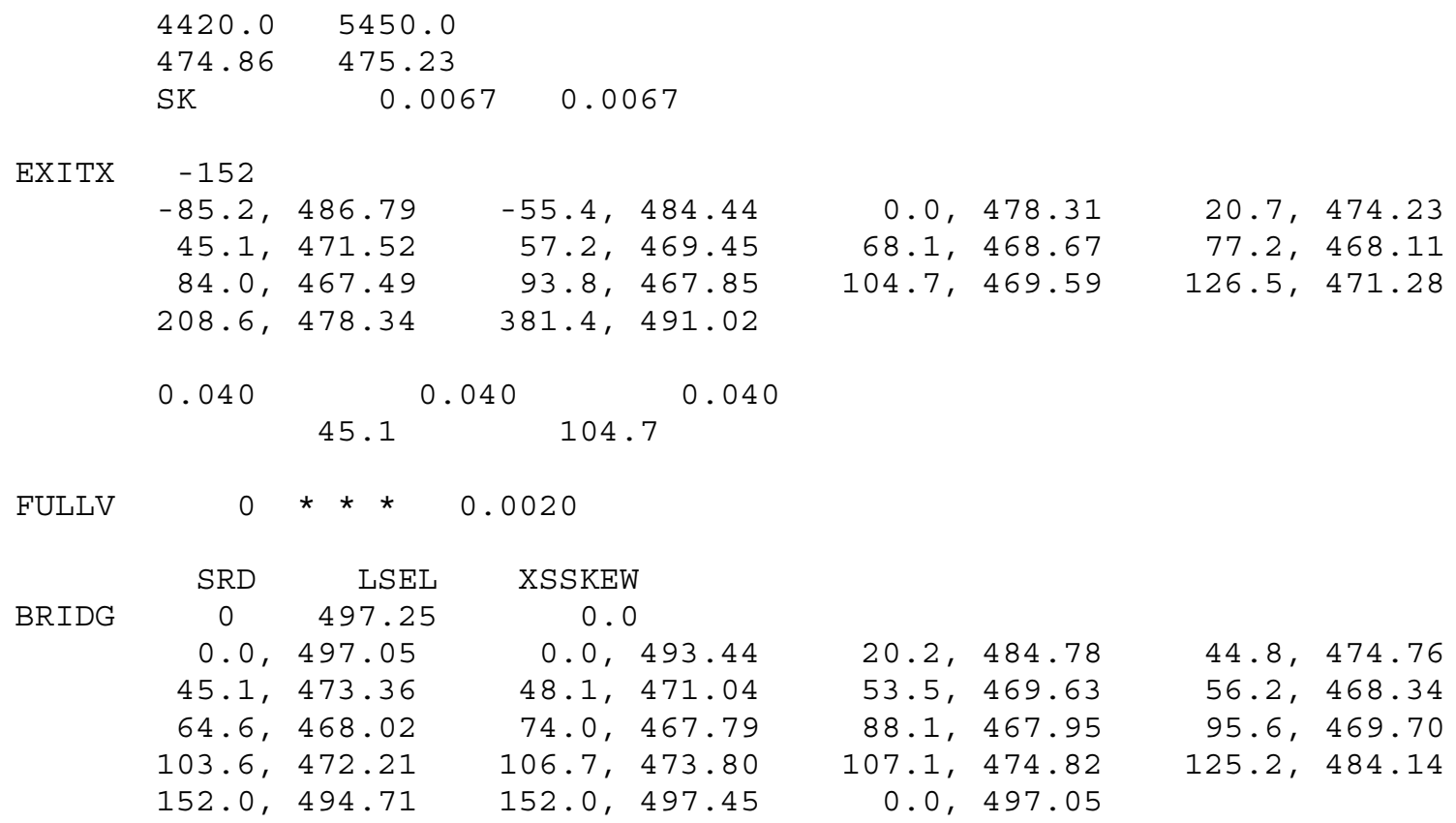

$54.4,468.54$

$111.2,471.08$

APPRO 


\section{APPENDIX B: \\ WSPRO OUTPUT FILE}




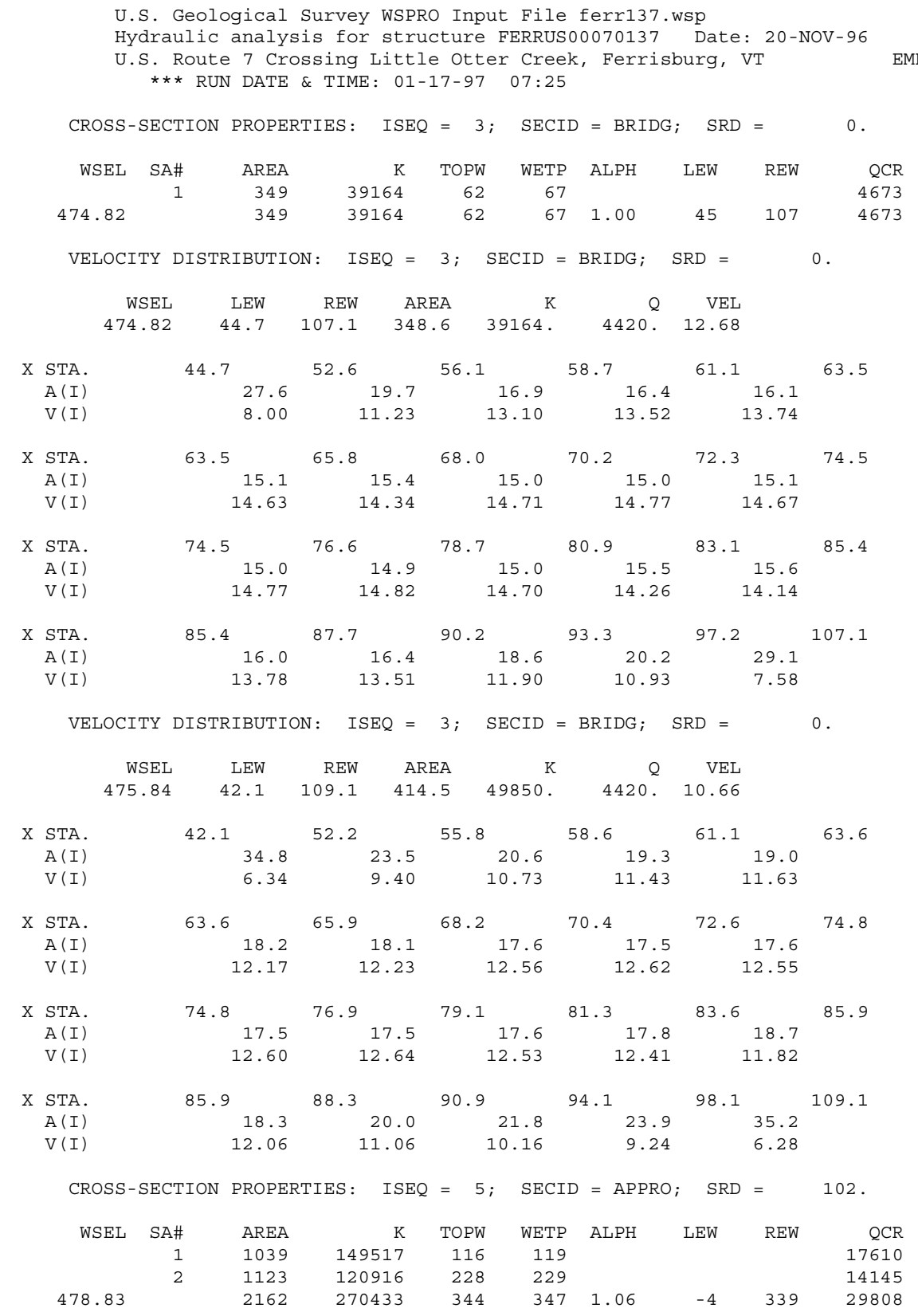

VELOCITY DISTRIBUTION $:$ ISEQ $=5 ; \quad \mathrm{SECID}=\mathrm{APPRO} ; \quad \mathrm{SRD}=102$.

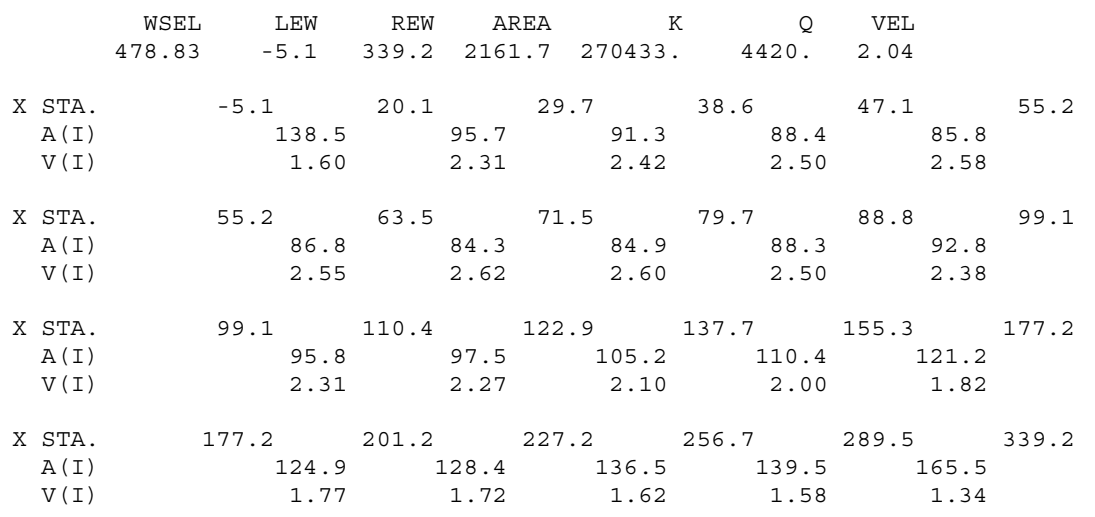


WSPRO OUTPUT FILE (continued)

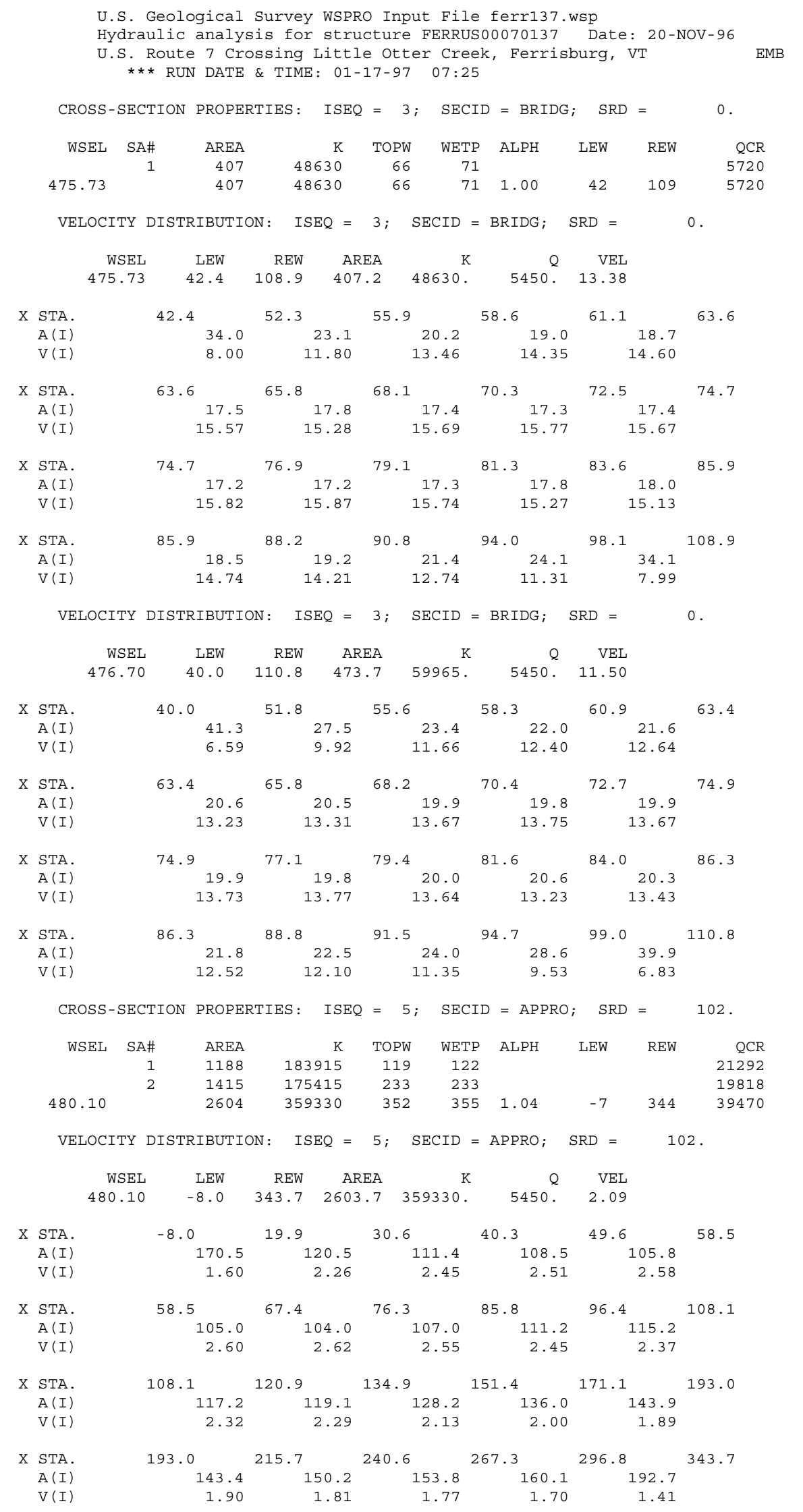


WSPRO OUTPUT FILE (continued)

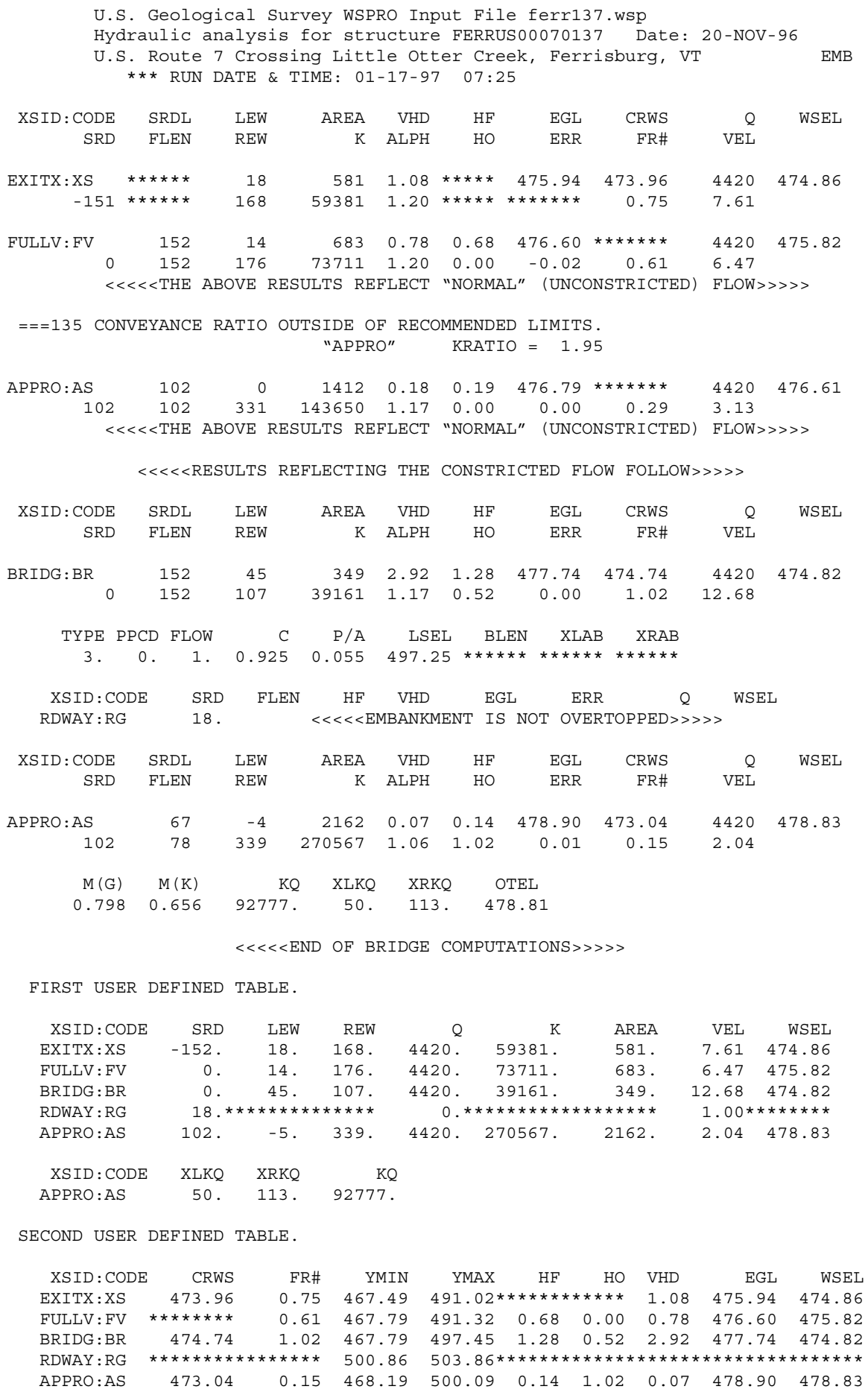


WSPRO OUTPUT FILE (continued)

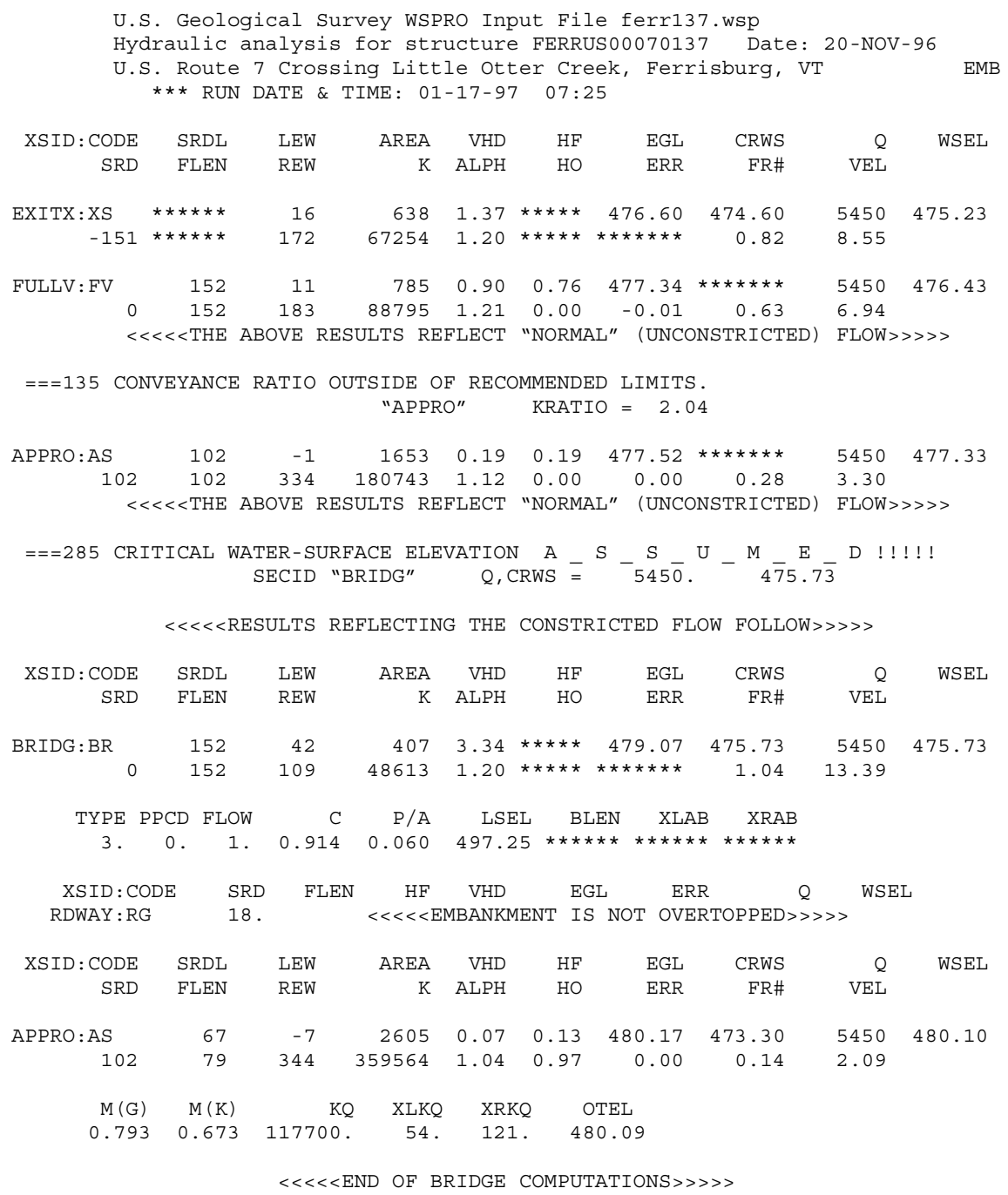

FIRST USER DEFINED TABLE.

\begin{tabular}{|c|c|c|c|c|c|c|c|c|}
\hline XSID : CODE & SRD & LEW & REW & $Q$ & K & AREA & VEL & WSEL \\
\hline EXITX:XS & -152. & 16. & 172 . & 5450 . & 67254 & 638 & 8.55 & 475.23 \\
\hline FULLV : FV & 0 . & 11. & 183. & 5450 . & 88795. & 785. & 6.94 & 476.43 \\
\hline BRIDG : BR & 0 . & 42 . & 109. & 5450 . & 48613 & 407 & 13.39 & 475.73 \\
\hline RDWAY : RG & \multicolumn{3}{|c|}{$18 . * * * * * * * * * * * * * *$} & \multicolumn{3}{|c|}{$0 . * * * * * * * * * * * * * * * * * * *$} & \multicolumn{2}{|c|}{$1.00 * * * * * * * *$} \\
\hline APPRO : AS & 102. & -8 & 344 . & 5450 . & 359564 . & 2605 . & 2.09 & 480.10 \\
\hline XSID : CODE & XLKQ & XRKQ & & & & & & \\
\hline APPRO: AS & 54. & 121. & 117700 & & & & & \\
\hline
\end{tabular}

SECOND USER DEFINED TABLE.

\begin{tabular}{|c|c|c|c|c|c|c|c|c|c|}
\hline XSID : CODE & CRWS & FR\# & YMIN & YMAX & $\mathrm{HF}$ & HO & VHD & EGL & WSEL \\
\hline EXITX:XS & 474.60 & 0.82 & 467.49 & $491.02 *$ & 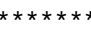 & $\star \star \star * \star *$ & 1.37 & 476.60 & 475.23 \\
\hline FULLV : FV & 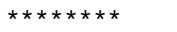 & 0.63 & 467.79 & 491.32 & 0.76 & 0.00 & 0.90 & 477.34 & 476.43 \\
\hline BRIDG : BR & 475.73 & 1.04 & 467.79 & $497.45 *$ & 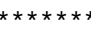 & $\star \star \star \star * *$ & 3.34 & 479.07 & 475.73 \\
\hline RDWAY : RG & 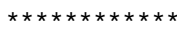 & 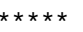 & 500.86 & $503.86 *$ & 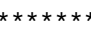 & $\star \star \star \star \star * *$ & 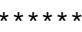 & 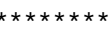 & 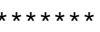 \\
\hline APPRO:AS & 473.30 & 0.14 & 468.19 & 500.09 & 0.13 & 0.97 & 0.07 & 480.17 & 480.10 \\
\hline $\mathrm{ER}$ & & & & & & & & & \\
\hline
\end{tabular}




\section{APPENDIX C:}

\section{BED-MATERIAL PARTICAL-SIZE DISTRIBUTION}




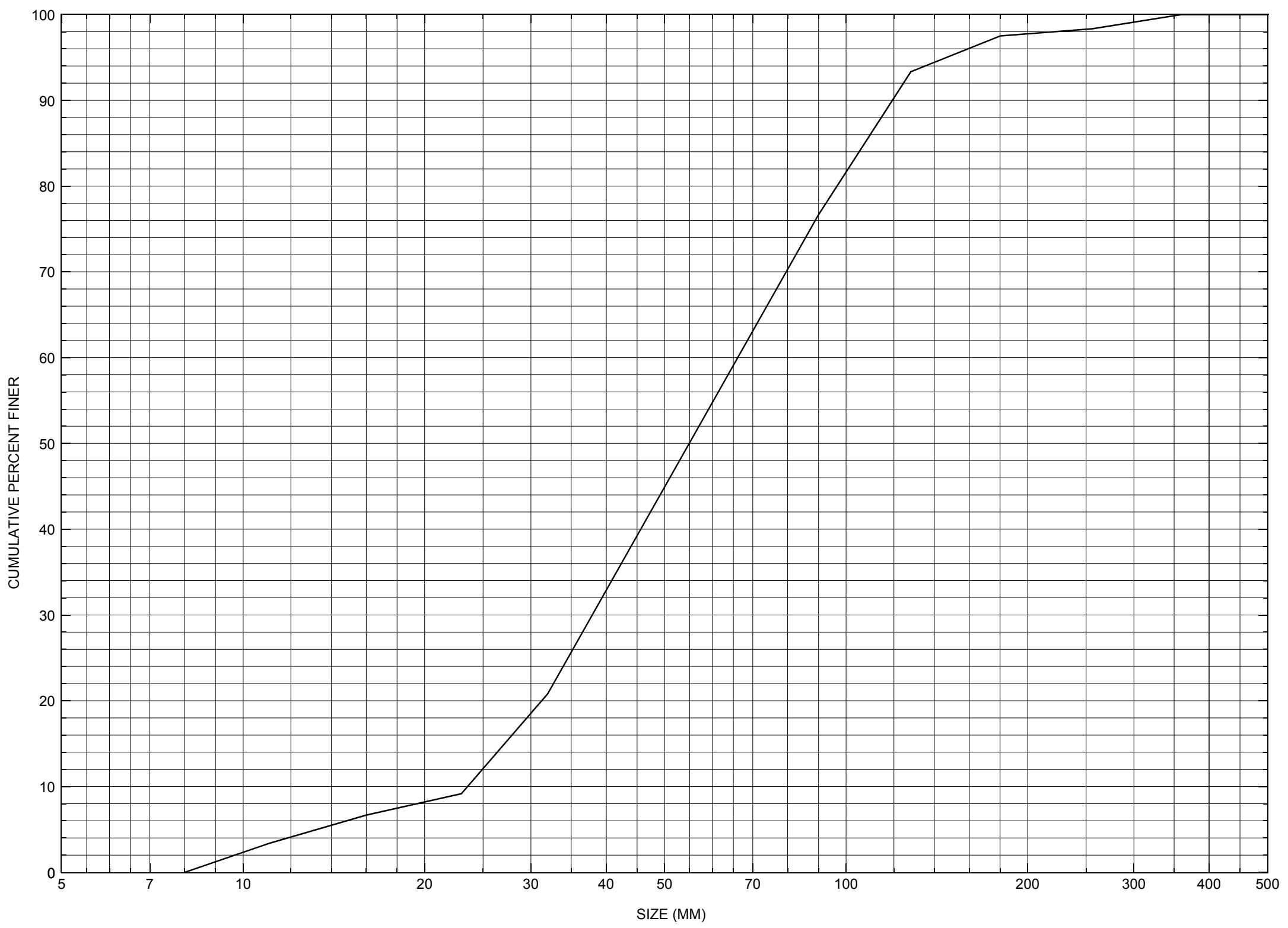

Appendix C. Bed material particle-size distribution for a pebble count in the channel approach of structure FERRUS00070137, in Ferrisburg, Vermont. 


\section{APPENDIX D: \\ HISTORICAL DATA FORM}




\section{Structure Number FERRUS00070137}

\section{General Location Descriptive}

Data collected by (First Initial, Full last name) $\underline{\mathbf{L}}$. Medalie

Date $(M M / D D / Y Y)+12 / 12 / \underline{95}$

Highway District Number (I - 2; nn) $\mathbf{0 5}$

Town (FIPS place code; I - 4; nnnnn) $\mathbf{2 6 2 7 5}$

Waterway ( $($ - 6) LITTLE OTTER CREEK

Route Number -

Topographic Map MONKTON

Latitude (I - 16; nnnn.n) $\mathbf{4 4 1 1 5}$
County (FIPS county code; I - 3; nnn)

Mile marker (I - 11; nnn.nnn) $\mathbf{0 0 0 0 0 0}$

Road Name (I - 7): -

Vicinity (I - 9) 1.1 MI TO JCT W VT 22A

Hydrologic Unit Code: 2010002

Longitude (i - 17; nnnnn.n) $\mathbf{7 3 1 4 6}$

\section{Select Federal Inventory Codes}

FHWA Structure Number (I - 8) $\mathbf{2 0 0 0 1 9 0 1 3 7 0 1 0 5}$

Maintenance responsibility $(I-21 ; n n) \quad \mathbf{0 1} \quad$ Maximum span length $(I-48 ; n n n n) \underline{\mathbf{0 0 5 7}}$

Year built (I - 27; YYYY) 1959

Structure length (I - 49; nnnnnn) $\underline{\mathbf{0 0 0 1 5 7}}$

Average daily traffic, ADT (I - 29; nnnnnn) $\underline{010900}$ Deck Width (I- 52; nn.n) $\mathbf{3 5 0}$

Year of ADT (I - 30; YY) $\mathbf{9 2}$

Channel \& Protection $(I-61 ; n) \underline{7}$

Opening skew to Roadway $(I-34 ; n n) \quad \mathbf{0 0}$

Waterway adequacy $(I-71 ; n) \underline{8}$

Operational status $(I-41 ; X) \quad \mathbf{A}$

Underwater Inspection Frequency $(I-92 B ; X Y Y) \_\mathbf{N}$

Structure type (I- 43; nnn) $\mathbf{3 0 2}$

Year Reconstructed (I - 106) $\mathbf{0}$

Approach span structure type (I - 44; nnn) $\mathbf{0 0 0}$ Clear span (nnn.n ft) _ _

Number of spans (I - 45; nnn) $\mathbf{0 0 3}$

Vertical clearance from streambed (nnn.n ft) $\underline{\mathbf{0 3 1 0}}$

Number of approach spans (I - 46; nnnn) $\mathbf{0 0 0 0}$ Waterway of full opening $\left(n n n . n \mathrm{ft}^{2}\right)$ -

Comments:

According to the structural inspection report dated 9/28/93, the structure is a 3-span, rolled beam bridge.

The stem of the right abutment has some minor cracking. Neither pier is located in the channel. The slopes in the pier area are protected with stone fill. The curtain wall at the left abutment is in good condition, except for some minor scaling. The channel takes a moderate turn into and out of the structure. 


\section{Bridge Hydrologic Data}

Is there hydrologic data available? $\underline{\mathbf{Y}}$ if No, type ctrl- $n$ h VTAOT Drainage area $\left(m i^{2}\right): \underline{\mathbf{5 4 . 8 4 4}}$ Terrain character: Rolling to mountainous

Stream character \& type: .

Streambed material:

Discharge Data (cfs):

$$
\begin{aligned}
& Q_{2.33}- \\
& Q_{50}-
\end{aligned}
$$

Record flood date $(M M / D D / Y Y)$ :

Estimated Discharge (cfs): Ice conditions (Heavy, Moderate, Light) :--

$$
\mathrm{Q}_{10} \frac{-}{\mathrm{Q}_{100}-}
$$$$
\mathrm{Q}_{25} \ldots
$$

Water surface elevation (ft): $(\mathrm{ft} / \mathrm{s}):$

The stage increases to maximum highwater elevation (Rapidly, Not rapidly): Rapidly

The stream response is (Flashy, Not flashy):

Describe any significant site conditions upstream or downstream that may influence the stream's stage: -

Watershed storage area (in percent):

The watershed storage area is: - _ (1-mainly at the headwaters; 2- uniformly distributed; 3-immediatly upstream oi the site)

Water Surface Elevation Estimates for Existing Structure:

\begin{tabular}{|l|l|l|l|l|l|}
\hline Peak discharge frequency & $Q_{2.33}$ & $Q_{10}$ & $Q_{25}$ & $Q_{50}$ & $Q_{100}$ \\
Water surface elevation (ft)) & - & - & - & - & - \\
Velocity $(\mathrm{ft} / \mathrm{sec})$ & - & - & - & - & - \\
\hline
\end{tabular}

Long term stream bed changes: -

Is the roadway overtopped below the $\mathrm{Q}_{100}$ ? (Yes, No, Unknown): $\mathbf{U} \quad$ Frequency: Relief Elevation (ft): Discharge over roadway at $Q_{100}\left(f^{3} / \mathrm{sec}\right)$ :

Are there other structures nearby? (Yes, No, Unknown): $\mathbf{U}$ Upstream distance (miles): Town: If No or Unknown, type ctrl-n os Highway No. : Structure No. :Year Built:

Clear span (ft): Clear Height (ft): Full Waterway $\left(f^{2}\right)$ : 
Downstream distance (miles): Town: Year Built:

Highway No. : Structure No. : Structure Type:

Clear span (ft): Clear Height $(f t)$ :

Full Waterway $\left(\mathrm{ft}^{2}\right)$ :

Comments:

Ordinary high water elev. $=\mathbf{1 5 2 . 0}$ feet; extreme high water elev. $=160.0$ feet $($ according to Dickens

Formula); low water elev. $=148.0$. Velocity of stream at high water stage is $8.3 \mathrm{fps}$ at the estimated discharge of $6800 \mathrm{cfs}$. The full-opening area $=\mathbf{3 0 0 0} \mathrm{sq}$. $\mathrm{ft}$. and the area below ordinary high water $=\mathbf{2 8 2} \mathrm{sq}$. ft.

Character of scour, drift, ice, all normal.

\section{USGS Watershed Data}

Watershed Hydrographic Data

Drainage area $(D A) \stackrel{56.73}{\mathbf{5 6}} \mathrm{mi}^{2}$

Watershed storage (ST)

Bridge site elevation

Main channel length 150 2.8 18.66 $10 \%$ channel length elevation

Main channel slope

(S) 17.15 $\mathrm{ft} / \mathrm{mi}$ $\%$ mi

Lake and pond area

1.59 $\mathrm{mi}^{2}$

Headwater elevation 900 $\mathrm{ft}$

Watershed Precipitation Data

Average site precipitation in Average headwater precipitation in

Maximum 2yr-24hr precipitation event $(124,2)$ in

Average seasonal snowfall (Sn) $\mathrm{ft}$ 


\section{Bridge Plan Data}

Are plans available? $\mathbf{Y}$ If no, type ctrl-n pl Date issued for construction (MM/YYYY): 4 / 1958

Project Number DF019-4(4)

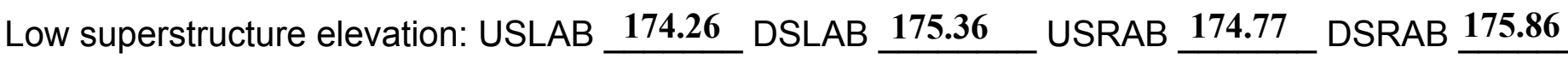

Benchmark location description:

No benchmarks noted on plans.

Reference Point (MSL, Arbitrary, Other): _-

Datum (NAD27, NAD83, Other): -

Foundation Type: 2 (1-Spreadfooting; 2-Pile; 3- Gravity; 4-Unknown)

If 1: Footing Thickness ___ Footing bottom elevation:

If 2: Pile Type: $\mathbf{2}$ (1-Wood; 2-Steel or metal; 3-Concrete) Approximate pile driven length: $\underline{\mathbf{2 0}}$

If 3: Footing bottom elevation:

Is boring information available? $\underline{\mathbf{Y}}$ If no, type ctrl-n bi Number of borings taken: $\underline{6}$

Foundation Material Type: 1 (1-regolith, 2-bedrock, 3-unknown)

Briefly describe material at foundation bottom elevation or around piles:

There were 8 drill borings documented on the plans. The bottom of the concrete left abutment footing is set in clay with piles driven through the clay into fine sand and gravel. Both pier footings are set in clay. The bottom of the concrete right abutment footing was set above the existing ground surface with piles driven into topsoil, clay and gravel, and clay hardpan.

\section{Comments:}

Plan sheet 30 indicates that there are spreadfootings at the piers and steel piles at the abutments. The footing thickness at the piers is 3 feet. The bottom elevation at the left pier is 140.35 feet while that at the right pier is $\mathbf{1 4 0 . 5 5}$ feet. The bottom of the left abutment concrete wall is shown at elevation 168.26 below which steel piles were driven to 20 feet on average. The bottom of the right abutment concrete wall is shown at elevation 168.77 below which steel piles were driven to 25 feet on average. Pier 1 upstream and downstream beam seat elevations were $\mathbf{1 7 4 . 3 6}$ feet and 175.46 feet, respectively. Pier 2 upstream and downstream beam seat elevations were 174.55 feet and 175.65 feet, respectively.

The low superstructure elevations shown above are the bridge seat elevations from the bridge plans. 


\section{Cross-sectional Data}

Is cross-sectional data available? $\mathbf{N}$ If no, type ctrl-n xs

Source (FEMA, VTAOT, Other)? -

Comments: NO CROSS SECTIONAL INFORMATION

\begin{tabular}{|l|l|l|l|l|l|l|l|l|l|l|l|}
\hline Station & & - & - & - & - & - & - & - & - & - & - \\
\hline Feature & - & - & - & - & - & - & - & - & - & - & - \\
\hline $\begin{array}{l}\text { Low cord } \\
\text { elevation }\end{array}$ & - & - & - & - & - & - & - & - & - & - & - \\
\hline $\begin{array}{l}\text { Bed } \\
\text { elevation }\end{array}$ & - & - & - & - & - & - & - & - & - & - & - \\
\hline $\begin{array}{l}\text { Low cord to } \\
\text { bed length }\end{array}$ & - & - & - & - & - & - & - & - & - & - & - \\
\hline Station & - & - & - & - & - & - & - & - & - & - & - \\
\hline Feature & - & - & - & - & - & - & - & - & - & - & - \\
\hline $\begin{array}{l}\text { Low cord } \\
\text { elevation }\end{array}$ & - & - & - & - & - & - & - & - & - & - & - \\
\hline $\begin{array}{l}\text { Bed } \\
\text { elevation }\end{array}$ & - & - & - & - & - & - & - & - & - & - & - \\
\hline $\begin{array}{l}\text { Low cord to } \\
\text { bed length }\end{array}$ & - & - & - & - & - & - & - & - & - & - & - \\
\hline
\end{tabular}

Source (FEMA, VTAOT, Other)?

Comments: -

\begin{tabular}{|l|l|l|l|l|l|l|l|l|l|l|l|}
\hline Station & & - & - & - & - & - & - & - & - & - & - \\
\hline Feature & - & - & - & - & - & - & - & - & - & - & - \\
\hline $\begin{array}{l}\text { Low cord } \\
\text { elevation }\end{array}$ & - & - & - & - & - & - & - & - & - & - & - \\
\hline $\begin{array}{l}\text { Bed } \\
\text { elevation }\end{array}$ & - & - & - & - & - & - & - & - & - & - & - \\
\hline $\begin{array}{l}\text { Low cord to } \\
\text { bed length }\end{array}$ & - & - & - & - & - & - & - & - & - & - & - \\
\hline Station & - & - & - & - & - & - & - & - & - & - & - \\
\hline Feature & - & - & - & - & - & - & - & - & - & - & - \\
\hline $\begin{array}{l}\text { Low cord } \\
\text { elevation }\end{array}$ & - & - & - & - & - & - & - & - & - & - & - \\
\hline $\begin{array}{l}\text { Bed } \\
\text { elevation }\end{array}$ & - & - & - & - & - & - & - & - & - & - & - \\
\hline $\begin{array}{l}\text { Low cord to } \\
\text { bed length }\end{array}$ & - & - & - & - & - & - & - & - & - & - & - \\
\hline
\end{tabular}




\section{APPENDIX E: \\ LEVEL I DATA FORM}


U. S. Geological Survey

Bridge Field Data Collection and Processing Form

Qa/Qc Check by: EW Date: 10 /9/96

\section{Structure Number FERRUS00070137}

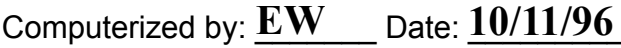

Reviewd by: $\quad$ EMB Date: 12/19/96

\section{A. General Location Descriptive}

1. Data collected by (First Initial, Full last name) R. BURNS

2. Highway District Number $\mathbf{0 5}$

Date $(M M / D D / Y Y) \underline{07} / \underline{01} / \underline{1996}$

County Addison (001)

Waterway (I - 6) Little Otter Creek

Route Number US 7

Mile marker $\mathbf{0 0 0 0 0 0}$

Town Ferrisburg (26275)

Road Name -

Hydrologic Unit Code: $\mathbf{0 2 0 1 0 0 0 2}$

3. Descriptive comments:

Located about 1.1 miles from the junction of VT $22 \mathrm{~A}$ with U.S. Route 7.

The structure is a three span, rolled steel beam bridge with spill-through embankment slopes in front of each abutment wall.

\section{B. Bridge Deck Observations}
4. Surface cover... LBUS 4
RBUS 4
LBDS 5
RBDS 6
Overall 4

(2b us, ds,lb,rb: 1- Urban; 2- Suburban; 3- Row crops; 4- Pasture; 5- Shrub- and brushland; 6- Forest; 7- Wetland)
5. Ambient water surface... US 1
UB 1
DS 1
(1- pool; 2- riffle)

6. Bridge structure type 2 (1- single span; 2- multiple span; 3- single arch; 4- multiple arch; 5-cylindrical culvert; 6- box culvert; or 7- other)
7. Bridge length 157 (feet)
Span length $\underline{\mathbf{5 7}}$
(feet)
Bridge width $\underline{\mathbf{3 5 . 0}}$ (feet)

\section{Road approach to bridge:}
8. LB $\underline{2}$ RB $\underline{0}$
( 0 even, 1- lower, 2- higher)
9. LB 1
RB 1
(1- Paved, 2- Not paved)

10. Embankment slope (run / rise in feet / foot)

US left

US right

\begin{tabular}{|c|c|c|c|}
\hline \multicolumn{2}{|c|}{ Protection } & \multirow{2}{*}{ 13.Erosion } & 14.Severity \\
\hline 11.Type & 12.Cond. & - & $\mathbf{1}$ \\
\hline $\mathbf{1}$ & $\mathbf{1}$ & $\mathbf{2}$ & - \\
$\mathbf{1}$ & $\mathbf{1}$ & $\mathbf{0}$ & - \\
$\mathbf{1}$ & $\mathbf{1}$ & $\mathbf{0}$ & - \\
\hline $\mathbf{1}$ & $\mathbf{1}$ & $\mathbf{0}$ & - \\
\hline
\end{tabular}

Bank protection types: 0- none; 1- < 12 inches;

2- < 36 inches; 3- < 48 inches;

4- < 60 inches; 5- wall / artificial levee

Bank protection conditions: 1- good; 2- slumped;

3- eroded; 4- failed

Erosion: 0 - none; 1- channel erosion; 2-

road wash; 3- both; 4- other

Erosion Severity: 0 - none; 1- slight; 2- moderate; 3- severe

\section{Channel approach to bridge (BF):}

15. Angle of approach: 15

16. Bridge skew: 15

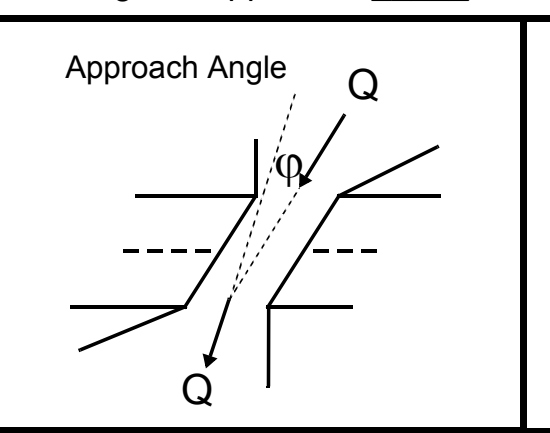

17. Channel impact zone 1:

Where? LB $(L B, R B)$

Range? 80 feet $\underline{\text { US }}$

Channel impact zone 2:

Where? RB (LB, RB) Bridge Skew Angle

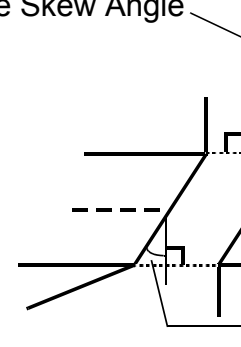

Q

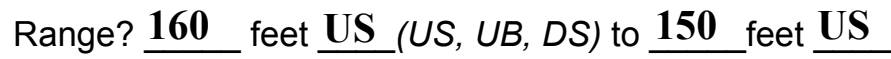

Impact Severity: 0- none to very slight; 1- Slight; 2- Moderate; 3- Severe 
18. Bridge Type: $1 \mathbf{b}$

1a- Vertical abutments with wingwalls

1 b- Vertical abutments without wingwalls

2- Vertical abutments and wingwalls, sloping embankment

Wingwalls perpendicular to abut. face

3- Spill through abutments

4- Sloping embankment, vertical wingwalls and abutments

Wingwall angle less than $90^{\circ}$.

19. Bridge Deck Comments (surface cover variations, measured bridge and span lengths, bridge type variations, approach overflow width, etc.)

On the upstream left bank, there is forest at about 300 feet upstream. The immediate bank is grass covered with a strip of trees and more pasture within two bridge lengths. The downstream right bank is forest except for a grass covered section between 100 feet and 150 feet downstream. The downstream left bank has a variety of trees, shrubs and grass coverage.

\section{Upstream Channel Assessment}

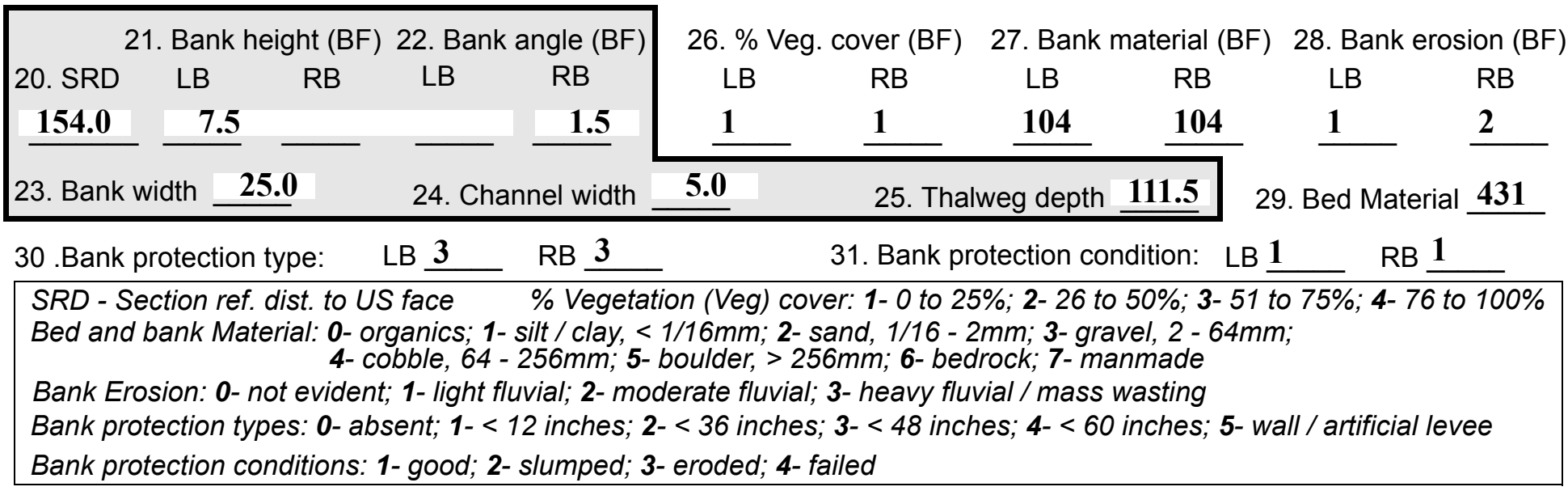

32. Comments (bank material variation, minor inflows, protection extent, etc.):

Right bank protection extends from the upstream bridge face to 35 feet upstream.

Left bank protection extends from 0 feet upstream to 70 feet upstream. 
37. Material: 10

38. Point or side bar comments (Circle Point or Side; Note additional bars, material variation, status, etc.):

Point bar is vegetated with tall grass and is mostly under 2 inches of water.

39. Is a cut-bank present? $\mathbf{Y}$ (Y or if $N$ type $c t r-n c b)$

41. Mid-bank distance: 230

43. Bank damage: 3

42. Cut bank extent: 300
40. Where? $\underline{\mathbf{R B}}(L B$ or $R B)$

feet $\underline{\mathbf{U S}}$ (US, UB) to $\underline{\mathbf{2 1 5}}$ feet $\underline{\mathbf{U S}}$ (US, UB, DS)

44. Cut bank comments (eg. additional cut banks, protection condition, etc.):

A $10 \mathrm{ft}$. wide section of the bank has slid down.

45. Is channel scour present? $\underline{\mathbf{Y}}$ (Y or if $N$ type ctrl-n cs) 46. Mid-scour distance: $\underline{\mathbf{0}}$

47. Scour dimensions: Length $\underline{\mathbf{2 5}}$ Width $\underline{\mathbf{1 0}}$ Depth: $\underline{\mathbf{1 . 2 5}}$ Position $\underline{\mathbf{1 0}} \%$ LB to $\underline{\mathbf{5 0}} \%$ RB

48. Scour comments (eg. additional scour areas, local scouring process, etc.):

The water depth is 3.25; average thalweg is 2 feet.

The scour hole extends from 20 feet upstream to 5 feet under bridge, measured from upstream bridge face.

49. Are there major confluences? $\mathbf{N}$

51. Confluence 1: Distance -

Confluence 2: Distance -

NO MAJOR CONFLUENCES
(Y or if $N$ type ctrl-n mc)

52. Enters on -

Enters on ( $L B$ or $R B)$ ( $L B$ or $R B)$
50. How many? -

53. Type(1-perennial; 2- ephemeral)

Type (1- perennial; 2- ephemeral)

\section{Under Bridge Channel Assessment}

55. Channel restraint (BF)? LB 2

56. Height (BF)
LB RB
$\mathbf{6 9 . 0}-$
58. Bank width (BF) =
(1- natural bank; 2- abutment; 3- artificial levee)

Bed and bank Material: 0- organics; 1- silt / clay, < 1/16mm; 2- sand, 1/16 - 2mm; 3- gravel, 2 - 64mm; 4- cobble, 64 - 256mm; 5- boulder, > 256mm; 6- bedrock; 7- manmade

Bank Erosion: 0- not evident; 1- light fluvial; 2- moderate fluvial; 3- heavy fluvial / mass wasting

64. Comments (bank material variation, minor inflows, protection extent, etc.):

451

The channel is currently flowing between the two piers. On both sides of the pier is type 3 stone fill. At about 20 feet up the slope towards the abutment, it changes to type 1 stone fill for another 20 feet, where it reaches the concrete abutment. About 6 feet of the type 3 stone fill is on the streamward side of both piers. 
65. Debris and Ice Is there debris accumulation?

(Yor $N)$ 66. Where? $\mathbf{N}$

(1- Upstream; 2- At bridge; 3- Both)

67. Debris Potential ( 1- Low; 2- Moderate; 3- High)

68. Capture Efficiency 1 (1-Low; 2- Moderate; 3- High)

69. Is there evidence of ice build-up? 2

Ice Blockage Potential $\mathbf{N}$ (1-Low; 2-Moderate; 3- High)

70. Debris and Ice Comments:

2

Capture efficiency and ice blockage potential are moderate because of piers.

\begin{tabular}{|l|c|c|c|c|c|c|c|c|}
\hline Abutments & $\begin{array}{c}71 . \text { Attack } \\
\angle \text { (BF) }\end{array}$ & $\begin{array}{c}72 \text {. Slope } \angle \\
\text { (Qmax) }\end{array}$ & $\begin{array}{c}\text { 73. Toe } \\
\text { loc. (BF) }\end{array}$ & $\begin{array}{c}\text { 74. Scour } \\
\text { Condition }\end{array}$ & $\begin{array}{c}75 . \text { Scour } \\
\text { depth }\end{array}$ & $\begin{array}{c}\text { 76. Exposure } \\
\text { depth }\end{array}$ & 77. Material & 78. Length \\
\hline LABUT & & - & $\mathbf{4 5}$ & $\mathbf{1}$ & $\mathbf{2}$ & $\mathbf{0}$ & $\mathbf{0 . 5}$ & $\mathbf{9 0 . 0}$ \\
\hline RABUT & $\mathbf{1}$ & $\mathbf{1 0}$ & $\mathbf{4 5}$ & & & $\mathbf{1}$ & $\mathbf{0}$ & $\mathbf{1 5 2 . 0}$ \\
\hline
\end{tabular}

Pushed: $L B$ or RB

Toe Location (Loc.): 0- even, 1- set back, 2- protrudes

Scour cond.: 0- not evident; 1- evident (comment); 2- footing exposed; 3-undermined footing; 4- piling exposed; 5- settled; 6- failed

Materials: 1- Concrete; 2- Stone masonry or drywall; 3- steel or metal; 4- wood

79. Abutment comments (eg. undermined penetration, unusual scour processes, debris, etc.):

$-$

1

\#74: The left abutment footing is not completely covered with stone fill like the right side.

80. Wingwalls:

Exist? Material? Scour Scour Exposure $\begin{array}{ll}81 . & \\ \text { Angle? Length? }\end{array}$ Condition? depth? depth?

USLWW:

USRWW: $\mathbf{N}$

DSLWW: -

DSRWW: -

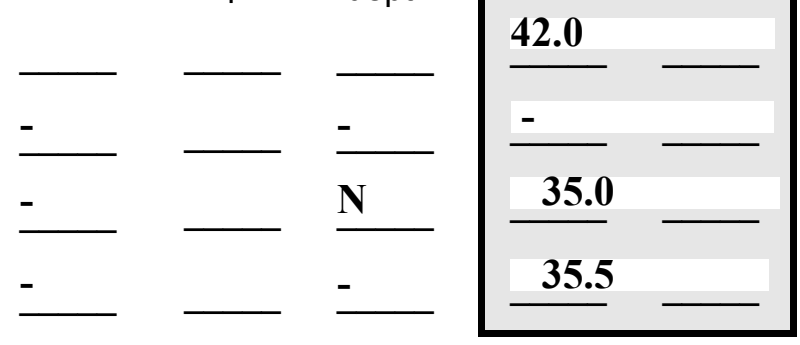

Wingwall materials: 1- Concrete; 2- Stone masonry or drywall; 3- steel or metal; 4- wood

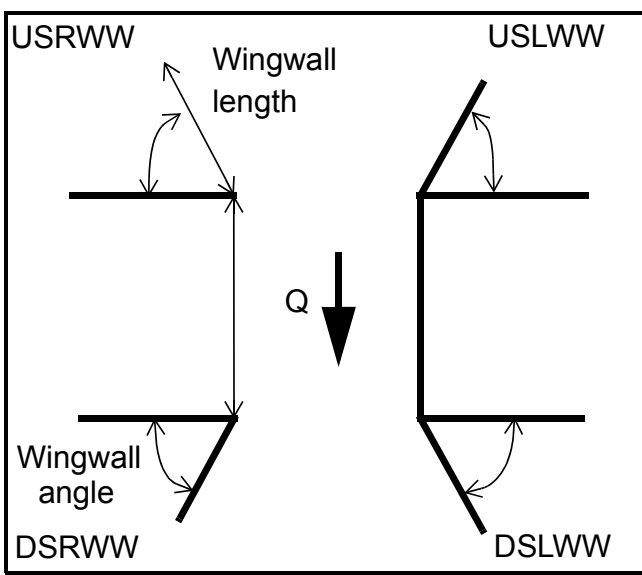

82. Bank / Bridge Protection:

\begin{tabular}{|l|l|l|l|l|l|l|l|c|}
\hline Location & USLWW & USRWW & LABUT & RABUT & LB & RB & DSLWW & DSRWW \\
\hline Type & - & - & N & - & - & - & $\mathbf{1}$ & $\mathbf{1}$ \\
\hline Condition & $\mathbf{N}$ & - & - & - & - & - & $\mathbf{1}$ & $\mathbf{1}$ \\
\hline Extent & - & - & - & - & - & $\mathbf{1}$ & $\mathbf{1}$ & - \\
\hline
\end{tabular}

Bank / Bridge protection types: 0- absent; 1- < 12 inches; 2- < 36 inches; 3- < 48 inches; 4- < 60 inches; 
83. Wingwall and protection comments (eg. undermined penetration, unusual scour processes, etc.):

-
-
-
-
-
-
-
-
-
-

\section{Piers:}

84. Are there piers? \#82 (Y or if $N$ type ctrl-n pr)

\begin{tabular}{|l|l|l|l|l|l|l|l|}
\hline \multirow{2}{*}{$\begin{array}{l}85 . \\
\text { Pier no. }\end{array}$} & \multicolumn{3}{|c|}{ width (w) feet } & \multicolumn{3}{c|}{ elevation (e) feet } \\
\cline { 2 - 9 } & w1 & w2 & w3 & e@w1 & e@w2 & e@w3 \\
\hline Pier 1 & - & - & - & - & - & - \\
\hline Pier 2 & - & $\mathbf{3 . 0}$ & $\mathbf{3 . 0}$ & - & $\mathbf{4 9 7 . 1 7}$ & $\mathbf{4 7 1 . 0 4}$ \\
\hline Pier 3 & - & $\mathbf{3 . 0}$ & $\mathbf{3 . 0}$ & - & $\mathbf{4 9 7 . 7 8}$ & $\mathbf{4 7 2 . 2 1}$ \\
\hline Pier 4 & - & - & - & - & - & - \\
\hline
\end{tabular}

\begin{tabular}{|l|l|l|l|l|}
\hline Level 1 Pier Descr. & \multicolumn{1}{|c|}{1} & \multicolumn{1}{|c|}{2} & \multicolumn{1}{|c|}{3} & \multicolumn{1}{|c|}{4} \\
\hline 86. Location (BF) & $:$ The & ment & slope & the \\
\hline 87. Type & pro- & is & , the & right \\
\hline 88. Material & tec- & type & pro- & and \\
\hline 89. Shape & tion & $\mathbf{1 .}$ & tec- & left \\
\hline 90. Inclined? & imm & Then & tion & bank \\
\hline 91. Attack $\angle$ (BF) & edi- & $\mathbf{2 0}$ & is & s. \\
\hline 92. Pushed & ately & feet & type & \\
\hline 93. Length (feet) & - & - & - & - \\
\hline 94. \# of piles & in & dow & $\mathbf{3}$ to & \\
\hline 95. Cross-members & front & n a & the & \\
\hline 96. Scour Condition & of & $\mathbf{4 5}$ & piers & \\
\hline 97. Scour depth & the & degr & on & \\
\hline 98. Exposure depth & abut & ee & both & \\
\hline
\end{tabular}

LFP, LTB, LB, MCL, MCM, MCR, RB, RTB, RFP

1- Solid pier, 2- column, 3- bent

1-Wood; 2- concrete; 3- metal; 4- stone

1- Round; 2- Square; 3- Pointed

Y-yes; $N$ - no

$L B$ or $R B$

0- none; 1- laterals; 2- diagonals; 3- both

0- not evident; 1- evident (comment);

2- footing exposed; 3- piling exposed;

4- undermined footing; 5- settled; 6- failed 
99. Pier comments (eg. undermined penetration, protection and protection extent, unusual scour processes, etc.):

Y
MCL
$\mathbf{1}$
$\mathbf{2}$
$\mathbf{3}$
$\mathbf{N}$
$\mathbf{0}$

100.

\section{E. Downstream Channel Assessment}

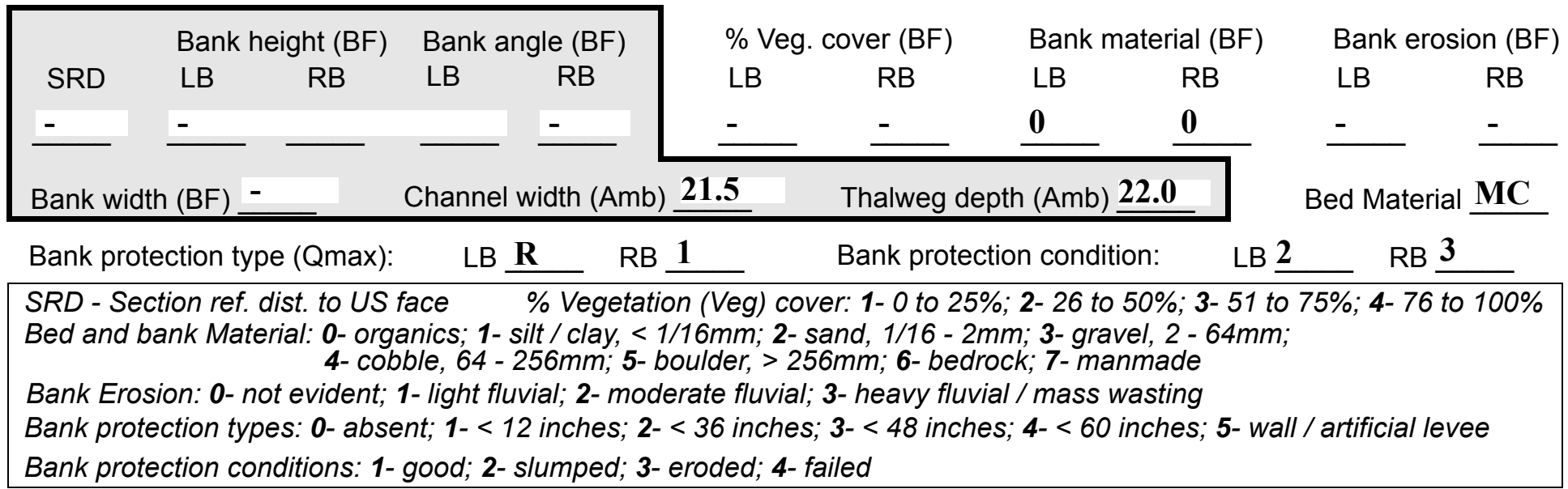

Comments (eg. bank material variation, minor inflows, protection extent, etc.):

$\mathbf{N}$

10

RB

0

$\mathbf{0}$

-

$-$

$-$

$-$

$-$

$-$

$-$

$-$

$-$

101. Is a drop structure present? _ ( $Y$ or $N$, if $N$ type ctrl-n ds) 102. Distance: __ feet
103. Drop: - feet
104. Structure material: -
(1- steel sheet pile; 2- wood pile; 3-concrete; 4- other)

105. Drop structure comments (eg. downstream scour depth): 
106. Point/Side bar present? (Y or $N$. if $N$ type ctrl-n pb)Mid-bar distance:

Mid-bar width: -

Point bar extent: feet -

(US, UB, DS) to feet (US, UB, DS) positioned $\%$ LB to $\%$ RB Material: Pie

Point or side bar comments (Circle Point or Side; note additional bars, material variation, status, etc.):

rs are protected on all sides by type 3 protection.

Is a cut-bank present? (Y or if $N$ type ctrl-n cb) Where? (LB or $R B)$

Mid-bank distance:

Cut bank extent: feet (US, UB, DS) to feet 1 (US, UB, DS)

Bank damage: $\mathbf{3}$ (1- eroded and/or creep; 2- slip failure; 3- block failure)

Cut bank comments (eg. additional cut banks, protection condition, etc.): 10

10

1

1

Is channel scour present? $\underline{451}$ (Y or if $N$ type ctrl-n cs) Mid-scour distance: $\underline{\mathbf{3}}$ Scour dimensions: Length 3 Width $\underline{1}$ Depth: 1 Positioned Rig \% LB to ht $\%$ RB Scour comments (eg. additional scour areas, local scouring process, etc.):

bank and left bank protection extends from downstream bridge face to 68 feet downstream.

Bank erosion is occurring downstream of the protection in the form of scallops along the bank.

Are there major confluences? ( $Y$ or if $N$ type ctrl-n $m c)$

How many?

Confluence 1: Distance

Enters on (LB or $R B)$

Type (1- perennial; 2- ephemeral)

Confluence 2: Distance

Enters on (LB or $R B)$

Type (1- perennial; 2- ephemeral)

Confluence comments (eg. confluence name):

\section{F. Geomorphic Channel Assessment}

107. Stage of reach evolution

1- Constructed

2- Stable

3- Aggraded

4- Degraded

5- Laterally unstable

6- Vertically and laterally unstable 
108. Evolution comments (Channel evolution not considering bridge effects; See HEC-20, Figure 1 for geomorphic descriptors): $\mathbf{N}$

$-$

NO DROP STRUCTURE

$\mathbf{N}$

-

$-$

$-$ 


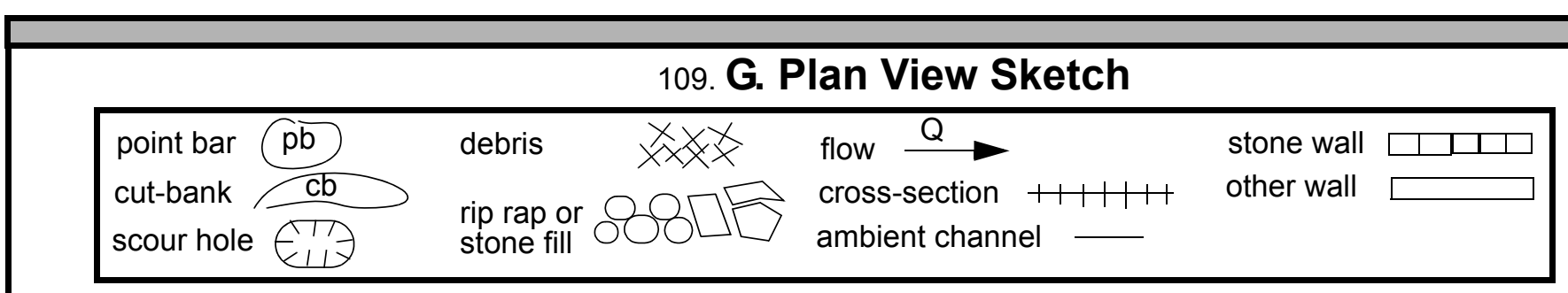


APPENDIX F:

SCOUR COMPUTATIONS 
SCOUR COMPUTATIONS

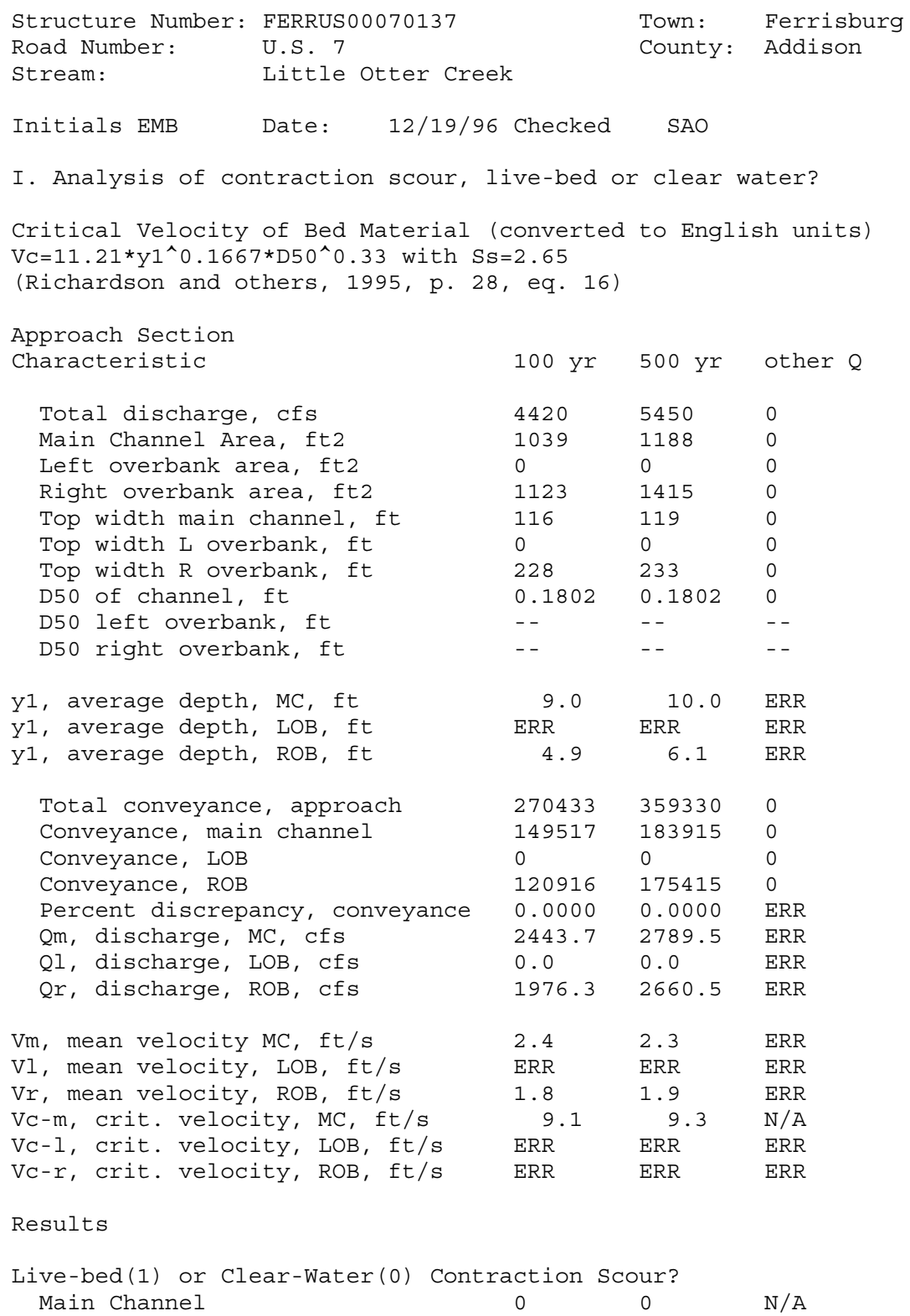




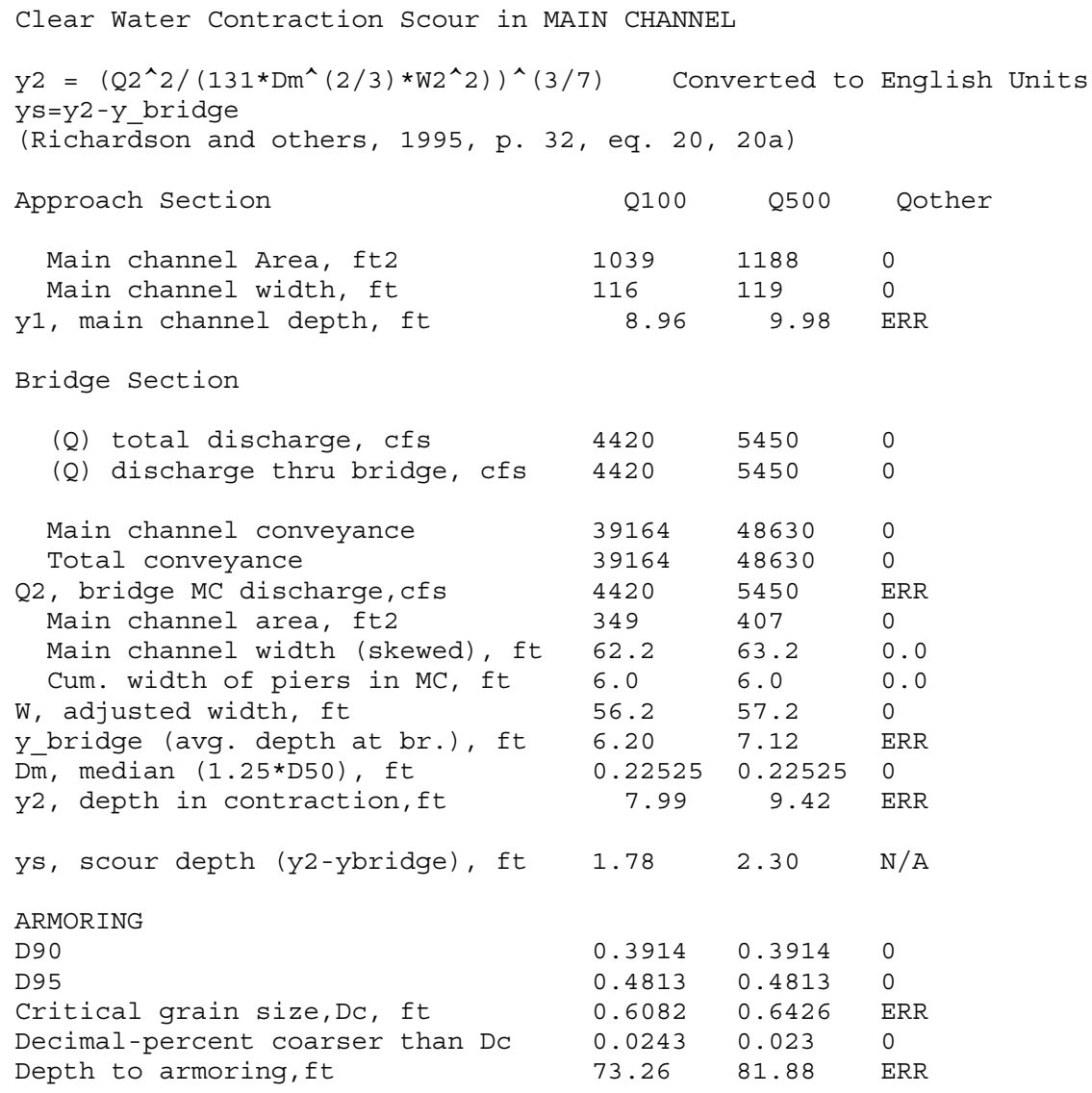


Abutment Scour

Froehlich's Abutment Scour

$\mathrm{Ys} / \mathrm{Y} 1=2.27 * \mathrm{~K} 1 * \mathrm{~K} 2 *\left(\mathrm{a}^{\prime} / \mathrm{Y} 1\right)^{\wedge} 0.43 * \mathrm{Fr} 1{ }^{\wedge} 0.61+1$

(Richardson and others, 1995, p. 48, eq. 28)

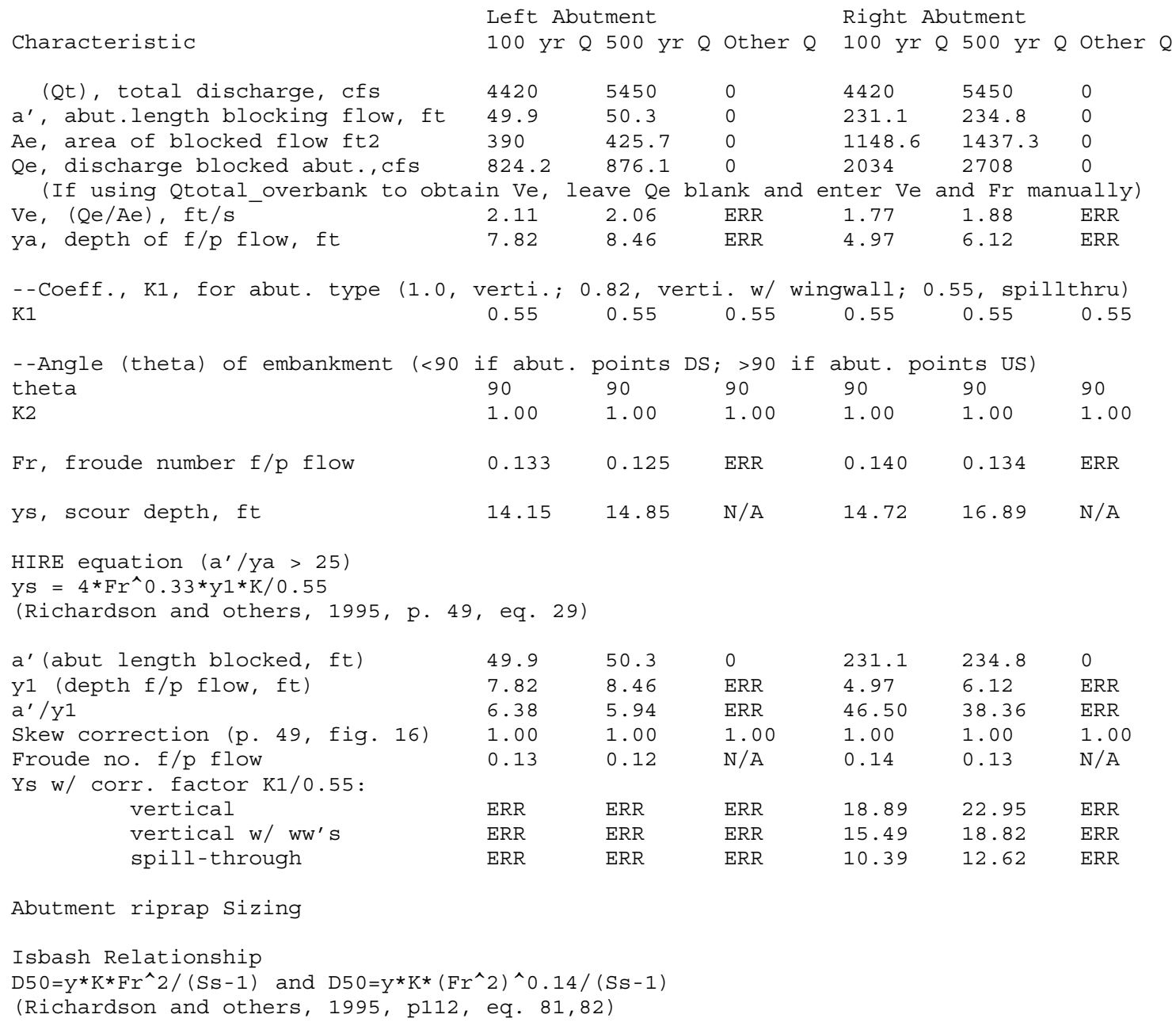




\begin{tabular}{|c|c|c|c|c|c|c|}
\hline Characteristic & Q100 & Q500 & Qother & & & \\
\hline $\begin{array}{l}\text { Fr, Froude Number } \\
\text { (Fr from the characteristic } V \text { and }\end{array}$ & $\begin{array}{l}1 \\
y\end{array}$ in & $\begin{array}{l}1 \\
\text { racted }\end{array}$ & $\begin{array}{c}0 \\
\text { section }\end{array}$ & ${ }^{1}$, bridge & $\begin{array}{l}1 \\
\text { section) }\end{array}$ & 0 \\
\hline$y$, depth of flow in bridge, ft & 6.20 & 7.12 & 0.00 & 6.20 & 7.12 & 0.00 \\
\hline ledian Stone Diameter for riprap at: & let & nt & & right abu & nent, & \\
\hline Fr< $<0.8 \quad$ (spillthro & ERR & ERR & 0.00 & ERR & ERR & 0.00 \\
\hline Fr>0.8 (spillthrough abut.) & 2.29 & 2.63 & ERR & 2.29 & 2.63 & ERR \\
\hline
\end{tabular}

Pier Scour(both live-bed and clear water scour)

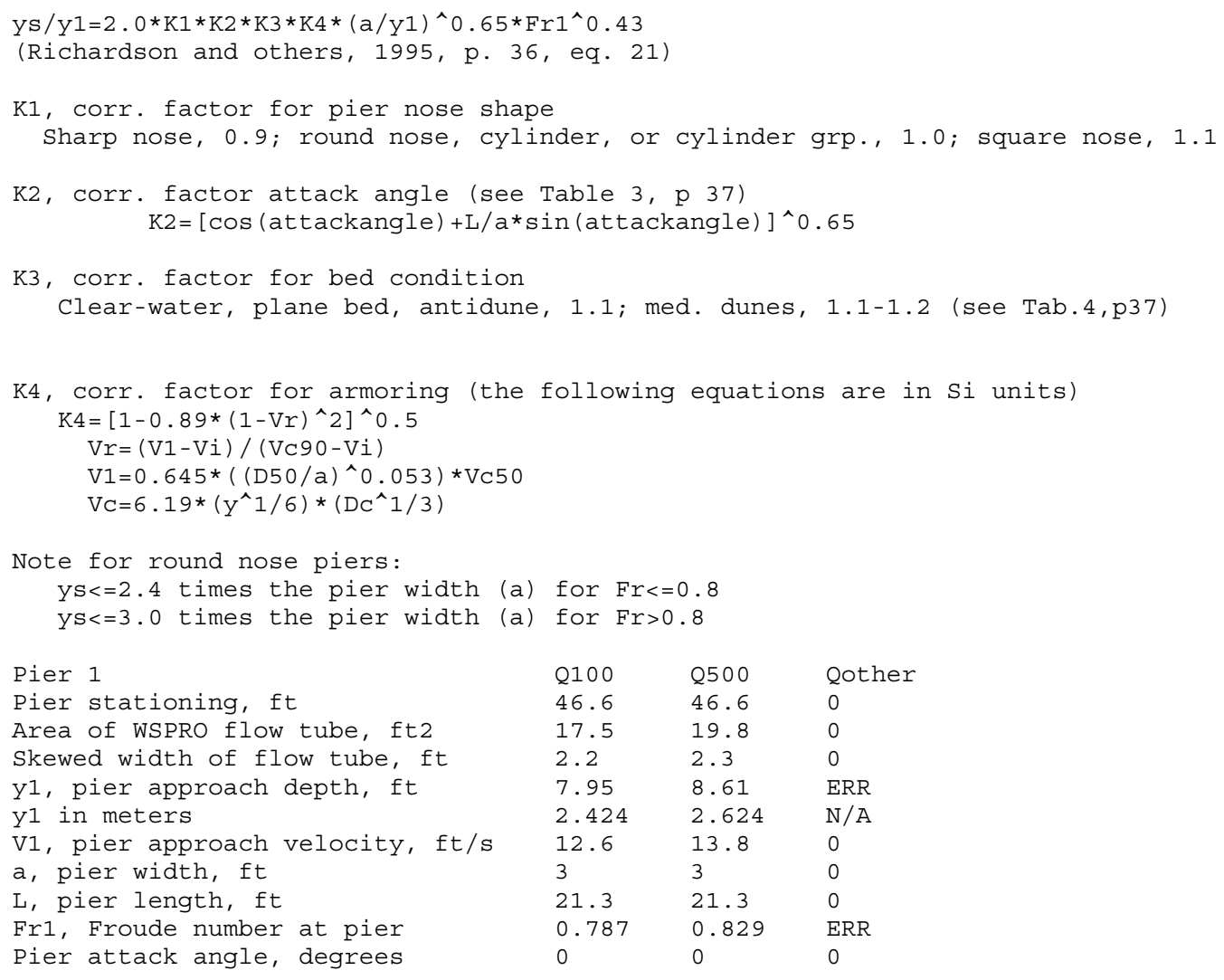

$\begin{array}{lll}\text { Q100 } & \text { Q500 } & \text { Qother } \\ 46.6 & 46.6 & 0 \\ 17.5 & 19.8 & 0 \\ 2.2 & 2.3 & 0 \\ 7.95 & 8.61 & \text { ERR } \\ 2.424 & 2.624 & \text { N/A } \\ 12.6 & 13.8 & 0 \\ 3 & 3 & 0 \\ 21.3 & 21.3 & 0 \\ 0.787 & 0.829 & \text { ERR } \\ 0 & 0 & 0\end{array}$




\begin{tabular}{|c|c|c|c|}
\hline K1, shape factor & 0.9 & 0.9 & 0 \\
\hline $\mathrm{K} 2$, attack factor & 1.00 & 1.00 & ERR \\
\hline K3, bed condition factor & 1.1 & 1.1 & 0 \\
\hline D50, ft & 0.1802 & 0.1802 & 0 \\
\hline $\mathrm{D} 50, \mathrm{~m}$ & 0.054922 & 0.054922 & 0 \\
\hline D90, ft & 0.3914 & 0.3914 & 0 \\
\hline D90, m & 0.119293 & 0.119293 & 0 \\
\hline Vc50, critical velocity (D50), m/s & 2.727 & 2.763 & $\mathrm{~N} / \mathrm{A}$ \\
\hline Vc90, critical velocity (D90), m/s & 3.532 & 3.579 & $\mathrm{~N} / \mathrm{A}$ \\
\hline Vi, incipient velocity, m/s & 1.515 & 1.536 & ERR \\
\hline Vr, velocity ratio & 1.153 & 1.307 & ERR \\
\hline K4, armor factor & 0.00 & 0.00 & $\mathrm{~N} / \mathrm{A}$ \\
\hline ys, scour depth (K4 applicable) ft & ERR & ERR & ERR \\
\hline ys, scour depth (K4 not applied) ft & 7.54 & 7.92 & ERR \\
\hline Pier 2 & Q100 & Q500 & Qot \\
\hline Pier stationing, ft & 105.2 & 105.2 & $\tilde{0}$ \\
\hline Area of WSPRO flow tube, ft 2 & 17.5 & 19.8 & 0 \\
\hline Skewed width of flow tube, ft & 2.2 & 2.3 & 0 \\
\hline y1, pier approach depth, ft & 7.95 & 8.61 & ERR \\
\hline y1 in meters & 2.424 & 2.624 & $\mathrm{~N} / \mathrm{A}$ \\
\hline V1, pier approach velocity, ft/s & 12.6 & 13.8 & 0 \\
\hline a, pier width, ft & 3 & 3 & 0 \\
\hline L, pier length, ft & 21.6 & 21.6 & 0 \\
\hline Fr1, Froude number at pier & 0.787 & 0.829 & ERR \\
\hline Pier attack angle, degrees & 10 & 10 & 0 \\
\hline K1, shape factor & 0.9 & 0.9 & 0 \\
\hline $\mathrm{K} 2$, attack factor & 1.69 & 1.69 & ERR \\
\hline K3, bed condition factor & 1.1 & 1.1 & 0 \\
\hline D50, ft & 0.1802 & 0.1802 & 0 \\
\hline $\mathrm{D} 50, \mathrm{~m}$ & 0.054922 & 0.054922 & 0 \\
\hline D90, ft & 0.3914 & 0.3914 & 0 \\
\hline D90, m & 0.119293 & 0.119293 & 0 \\
\hline Vc50, critical velocity (D50), m/s & 2.727 & 2.763 & $\mathrm{~N} / \mathrm{A}$ \\
\hline Vc90, critical velocity (D90), m/s & 3.532 & 3.579 & $\mathrm{~N} / \mathrm{A}$ \\
\hline Vi,incipient velocity,m/s & 1.515 & 1.536 & ERR \\
\hline Vr, velocity ratio & 1.153 & 1.307 & ERR \\
\hline K4, armor factor & 0.00 & 0.00 & $\mathrm{~N} / \mathrm{A}$ \\
\hline ys, scour depth, (K4 applicable) ft & ERR & ERR & ERR \\
\hline ys, scour depth, (K4 not applied)ft & 12.72 & 13.37 & ERR \\
\hline
\end{tabular}

$\mathrm{D} 50=0.692(\mathrm{~K} * \mathrm{~V})^{\wedge} 2 /(\mathrm{SS}-1) * 2 * \mathrm{~g}$

(Richardson and others, 1995, p.115, eq. 83)

Pier-shape coefficient (K), round nose, 1.5 ; square nose, 1.7 Characteristic avg. channel velocity, $\mathrm{V},(\mathrm{Q} / \mathrm{A})$ :

(Mult. by 0.9 for bankward piers in a straight, uniform reach, up to 1.7 for a pier in main current of flow around a bend)

Pier 1

$\mathrm{K}$, pier shape coeff.

$\mathrm{V}$, char. aver. velocity, ft/s

$\begin{array}{lll}\text { Q100 } & \text { Q500 } & \begin{array}{l}\text { Qother } \\ 1.5\end{array} \\ 1.5 & 0 \\ 12.7 & 13.4 & 0 \\ 2.36 & 2.63 & 0.00 \\ & & \\ 1.5 & 1.5 & 0 \\ 12.7 & 13.4 & 0 \\ 2.36 & 2.63 & 0.00\end{array}$

D50, median stone diameter, ft

Pier 2

$\mathrm{K}$, pier shape coeff.

$\mathrm{V}$, char. aver. velocity, ft/s

$\begin{array}{lll}2.36 & 2.63 & 0.00\end{array}$ 
